Working Paper in Economics No. 791

\title{
Determinants of Economies of Scope in Retail
}

Florin Maican and Matilda Orth

Department of Economics, August 2020 


\title{
Determinants of Economies of Scope in Retail*
}

\author{
Florin Maican ${ }^{\dagger}$ and Matilda Orth ${ }^{\ddagger}$
}

July 10, 2020

\begin{abstract}
This paper studies the determinants of economies of scope and quantifies their impact on the extensive and intensive product margins in retail. We use a framework based on a multiproduct technology to model stores' incentives to expand product variety. Using novel Swedish data on product categories and stores, we find that high-productivity stores offer more product categories and sell more of all product categories. Stores with high demand shocks specialize in fewer product categories and sell more top-selling product categories. Policy simulations show that investments in technology increase the extensive and intensive product margins, especially benefitting stores in urban markets because of their productivity advantage. Learning from demand to increase productivity and variety is crucial in rural markets. Reducing the role of uncertainty in both productivity and demand shocks endorses product variety and raises sales and market share.
\end{abstract}

Keywords: economies of scope; productivity; retail; product variety; technology; competition JEL Classification: L11, L13, L25, L81, M21

${ }^{*}$ We thank Dan Ackerberg, Jan De Loecker, Paul Grieco, Bo Honoré, Mitsukuni Nishida, Yutec Sun, Jo Van Biesebroeck, Frank Verboven, Eric Verhoogen, and Hongsong Zhang and seminar participants at the IIOC, EARIE, and KU Leuven for their valuable comments. Financial support from Formas and Swedish Competition Authority is gratefully acknowledged.

${ }^{\dagger}$ University of Gothenburg, CEPR, and Research Institute of Industrial Economics (IFN), E-mail: maicanfg@gmail.com

${ }^{\ddagger}$ Research Institute of Industrial Economics (IFN), Box 55665, SE-102 15, Stockholm, Sweden, Phone +46-8665 4531, E-mail: matilda.orth@ifn.se 


\section{Introduction}

Services and retail businesses account for a rapidly growing share of economic activity. In recent years, there have been ample investments in new technologies such as mobile payment systems, a drastic increase in warehouse clubs and a shift in consumer preferences from products to services (Hortacsu and Syverson, 2015; Goolsbee, 2020). These structural changes require retailers to improve their businesses of buying multiple products from wholesalers and efficiently delivering them to consumers with quality. Buildings, equipment and supply chain facilities yield economies of scope that make it cheaper to sell many products together than to sell them separately (Panzar and Willig, 1981). Despite massive changes in the retail landscape, we lack knowledge about the determinants of economies of scope and their impact on the extensive and intensive product margins. ${ }^{1}$

This paper studies the determinants of economies of scale and scope in retail using a framework that models stores' multi-product sales technology and the local market environment. We explore the tradeoff between productivity and demand shocks for offering product variety. We estimate the model using novel and detailed data on product categories and stores in Swedish retail between 2003 and 2009. Then, we evaluate how investment in technology, demand, learning and uncertainty drive the number of product categories (extensive margin), sales per product category (intensive margin), store-level sales and market shares. The analysis explores differences across rural and urban markets which is of interest to policymakers in light of regional development programs containing, for instance, investment subsidies.

Descriptive patterns in the data motivate our research framework. We measure product variety by the number of product categories a store offers for sale. ${ }^{2}$ Stylized facts show that stores with high market shares have high labor productivity, sell many product categories, and sell more per product category. Our data also suggest that it is important to explore heterogeneity across local markets and dynamic patterns over time, as indicated by the increase in the median market share, the four-firm concentration ratio, and the Herfindahl index [HHI].

\footnotetext{
${ }^{1}$ See Ellickson (2007), Basker et al. (2012), Hortacsu and Syverson (2015), and Hsieh and Rossi-Hansberg (2019).

${ }^{2}$ Product variety has been introduced by the entry literature (i.e., pay a fixed cost to increase variety), but we still need explanations for why firms hold multiple products in service industries. In general, economies of scope can appear from two sources: local complementarities and fixed costs (Gorman, 1985; Ellickson, 2007). Local complementarities imply that a higher level of output for one product reduces the marginal cost of other outputs. Fixed costs can ensure economies of scope in the absence of local complementarities.
} 
This descriptive evidence is consistent with the idea that stores utilize economies of scale and scope and productivity improvements to offer a wider variety of products. Based on this, our framework explicitly models the complementarities between economies of scale and scope in a local market setting.

We model economies of scope inside the multi-product technology, which provides a better understanding of the role of adjustment in stores' inputs for altering product variety. ${ }^{3}$ The gains from selling a larger variety arise from lower average costs or from increasing sales in new related product markets. Adjustments in product categories occur because retailers change their inputs or target a better match with local market demand. How many product categories to offer and how much to sell of each category are open empirical questions that depend on store resources and local demand conditions.

Our model highlights mechanisms through which productivity and demand shocks drive intensive and extensive margins. We use the implications of the equilibrium behavior of the store's dynamic optimization problem to recover two sources of store-level heterogeneity, i.e., revenue productivity and demand shocks, which are both observed by stores but not by the researcher. ${ }^{4}$ The evolution of revenue productivity is under store control, while the evolution of demand shocks is not under store control. Our measure of demand shocks includes features related to product quality, location, checkout speed, the courteousness of store employees, parking, bagging services, and cleanliness. To recover revenue productivity and demand shocks, we rely on two output equations - product sales and market share index functions - and store's demand functions for labor and inventories accounting for investment in technology, product variety and the local environment in which a store operates (Doraszelski and Jaumandreu, 2013; Kumar and Zhang, 2018; Maican and Orth, 2019). ${ }^{5}$ Market shares contain information about demand shocks, and rich sales data for the universe of stores allow us to use local market shares together with demand for inventories to recover external demand shocks. Important for identification is that the sales equation depends on both productivity and demand shocks, whereas the market

\footnotetext{
${ }^{3}$ See Mundlak (1964), Fuss and McFadden (1978), and Maican and Orth (2019).

${ }^{4}$ Unlike in manufacturing, is difficult to define and measure technical productivity in services due to complexity of product aggregation and economies of scale and scope (Oi, 1992).

${ }^{5}$ Carrying cost of inventories represents approximately 25 percent of the value of inventories and includes: capital cost, storage space cost, inventory service cost, and inventory risk cost. To avoid stock-outs, retailers spend more money on financing inventories than on advertising. Kumar and Zhang (2018) use the cost of goods to recover the distribution of demand shocks in manufacturing but do not model product variety.
} 
share index function only depends on demand shocks (Ackerberg et al., 2007). We allow stores to learn from demand, i.e., received demand shocks provide information that is used by stores to improve their future productivity. ${ }^{6}$ This mechanism of learning about demand has not yet received much attention in the structural productivity literature.

This paper contributes to the recent literature on the development in services and retail industries. The analysis focuses on the supply side to investigate the determinants of economies of scope and explore differences between rural and urban markets. We model the role of technology, inputs and the dynamic nature of product variety and store primitives. ${ }^{7}$ The proposed framework provides a tractable way of analyzing economies of scope at the firm/establishment level using Census data combined with data on product categories and sales per category. Our framework is applicable to any industry where many firms operate and offer a wide range of products for which data on price and detailed product characteristics are not available. In the rare case that data on product-level prices are available and can be linked to Census data on services firms, our framework can be integrated with a more general demand framework that allows for rich substitution patterns between products. ${ }^{8}$ While we do not use a dynamic game, the store's market share is affected not only by its own product variety choice but also by the product variety choices of other stores in the local market. The proposed framework to study economies of scope is appealing from a policy perspective because it pays attention to the in-

\footnotetext{
${ }^{6}$ The recent literature emphasizes that external factors such as trade liberalization and entry regulations are important determinants of this heterogeneity (De Loecker, 2011; Maican and Orth, 2015; Maican and Orth, 2017). These explanations are added on top of factors inside the firm such as R\&D investments (Doraszelski and Jaumandreu, 2013) or management (Syverson, 2011). Braguinsky et al. (2015) highlight the link between inventories, productivity and profitability.

${ }^{7}$ Analyzing the link between scale and scope, Basker et al. (2012) emphasize that economies of scale on the cost side and demand for one-stop shopping yields an increase in the number of stores and products. Hsieh and Rossi-Hansberg (2019) argue that consolidation services is tied to investments in ICT-technologies that enable stores to produce at scale and to increase specialization among the top firms. See, e.g., Gorman (1985), Ellickson (2007), Basker et al. (2012), Bronnenberg and Ellickson (2015), Hortacsu and Syverson (2015), Berry et al. (2019), Ellickson et al. (2019).

${ }^{8}$ For example, a constant expenditure specification in an aggregate nested logit model. That retailers commonly offer hundreds or thousands of separate products makes it difficult to handle individual product data together with Census data. As a matter of fact, some aggregation is needed to make the analysis manageable. Most of the demand literature on product variety that allows for rich substitution patterns across products does not model the role of supply side technology, inputs (labor, capital, inventory) or the dynamic nature of product variety and store primitives. This paper complements the literature on product variety using discrete choice demand models with product data. See, e.g., Berry and Waldfogel (2001), Draganska and Jain (2005), Sweeting (2010), Sweeting (2013), Eizenberg (2014), Berry et al. (2016), Quan and Williams (2018), Adams and Williams (2019), Fan and Yang (2019).
} 
dustry as a whole and explores heterogeneity across geographic areas.

This paper also contributes to the literature that emphasizes the role of technology and demand in understanding firm performance, which mainly focuses on manufacturing (e.g., Olley and Pakes, 1996; Foster et al., 2008; Collard-Wexler, 2013; Asker et al., 2014; Collard-Wexler and De Loecker, 2015). ${ }^{9}$ We highlight the tradeoff between productivity improvements and the level of demand shocks under uncertainty for key performance indicators such as sales per product, store-level sales and market shares in rural and urban markets. In particular, we contribute to the literature that uses the implications of equilibrium behavior for firms' decisions on inputs to estimate productivity (Olley and Pakes, 1996). ${ }^{10}$ Most of the literature on productivity estimation uses single-output technology and ignores multi-product technology, which renders inference on multi-product questionable (Bailey and Friedlaend, 1982). Because our multiproduct approach uses inputs at the firm/establishment level, identification and estimation are based on the well-established two-step methods in the production function literature (see Ackerberg et al., 2007 survey). We explicitly model how store productivity and demand shocks affect the sales of product categories using a multi-product technology function with known theoretical micro foundations for multi-product production and profit maximization (e.g., Mundlak, 1964; Fuss and McFadden, 1978). By applying our approach to data on product categories and stores, our work is linked to a recent strand of research on understanding the productivity of multi-product firms in manufacturing (e.g., De Loecker et al., 2016; Dhyne et al., 2017) and a companion paper on entry regulations in retail (Maican and Orth, 2019). ${ }^{11}$

The results show clear evidence that productivity improvements expand the intensive and extensive product margins. Stores sell more product categories and increase their sales, es-

\footnotetext{
${ }^{9}$ By modeling the relationship between multi-product technology and productivity, this paper adds to the literature that explores heterogeneity in performance in services, e.g., Basker (2007), Basker (2015), Maican and Orth (2015), Grieco and McDevitt (2017), Maican and Orth (2017), and Decker et al. (2018).

${ }^{10}$ See also, Levinsohn and Petrin (2003), Doraszelski and Jaumandreu (2013), Ackerberg et al. (2015), and Gandhi et al. (2018).

${ }^{11}$ With the exception of Dhyne et al. (2017), this literature estimates input shares, which is difficult in retail. The nature of retail businesses suggests that it in most cases does not make sense to allocate employees to specific product categories. In addition, splitting capital is even more difficult in services. De Loecker et al. (2016) and Dhyne et al. (2017) estimate productivity in manufacturing accounting for multi-product and using physical quantity, i.e., they eliminate average price from the productivity measure (see also, Valmari, 2016; Orr, 2018). Analyzing the impact of entry regulation on product variety, Maican and Orth (2019) present a general result on the identification of the transcendental multi-output service technology and discuss the restrictions on the parameters that need to be satisfied for profit maximization.
} 
pecially among bottom-selling product categories. Higher demand shocks, on the other hand, contract the extensive product margin and encourage specialization. Stores with high demand shocks thus focus on fewer product categories and sell more of their top-selling categories. Taken together, higher productivity and demand shocks increase store-level sales and market shares. We use the estimated model to quantify gains from improving economies of scope, which affects store sales. We find that the increase in store median sales is two percentage points higher in rural than in urban markets when improving economies of scope by fifteen percent for all stores.

Policy experiments based on simulations of the model evaluate the impact of investment in technology, increasing demand and learning as well as reducing uncertainty in rural and urban markets. Investment in technology increases intensive and extensive product margins, store-level sales and market shares. Thirty percent higher investments for all stores yields a two percent median increase in a store's product categories and a two percent increase in sales per product category. Store-level sales increase four percent in urban markets but only two percent in rural markets. Stores in urban markets benefit more from technology investments because of their productivity advantage relative to stores in rural markets. The results show that an increase in technology stock induces substitution between labor and capital and better management with inventory, especially in rural markets. The findings are interesting for policymakers in light of regional development programs that subsidize investments (Nordregio, 2011, SCB, 2015).

A larger market size and/or higher income in the local market promote specialization. The number of product categories in a store decreases by three percent if population or income increases by thirty percent. More intense learning from demand generates a small increase in product-level and store-level sales, though the magnitude is about double in rural than in urban markets. To better utilize information about demand is thus important for stores' performance in rural areas.

Reducing the role of uncertainty in productivity and demand shocks increases extensive and intensive product margins, sales and market shares. Median store sales increase by as much as fifteen percent when the persistence in both productivity and demand shocks rises by five percent each. Productivity improvements outweigh specialization from higher demand shocks, which yields a four percent net increase in the median number of product categories. Reducing the role of uncertainty in received demand shocks associated with the quality of shopping 
benefits consumers in urban markets more, consistent with the finding of more specialization in these markets.

The next section presents the Swedish retail industry and the data. Section 3 presents the model and discusses the identification and estimation. Section 4 presents the empirical results. Section 5 shows the findings of various policy experiments using the estimated model. Section 6 presents robustness checks, and Section 7 summarizes and draws conclusions.

\section{Swedish retail trade and data}

Retail trade stands for a substantial share of all workplaces in Sweden, and the sector employs more than 150,000 individuals (SCB, 2015). There has been a drastic change in the retail landscape during recent decades. The rural areas of Sweden have experienced depopulation, lack of jobs and declining service provision. People have moved to cities leaving the country-side areas behind. The demographic changes across Sweden have occurred along with a considerable structural change in retail trade. Most of the retailers are situated in localities where the majority of the population lives. Stores have become larger and to a larger extent concentrate in cities and metropolitan areas. Sweden is divided into 290 municipalities, where 47 of them (16 percent) do not have at least five retail trade firms or have at least four retail trade firms that together employ at least 100 employees. As a result, policymakers have spent ample time and interest in policy discussions about the development of retail services in rural markets. Several regional development programs have been implemented to support improvements in rural areas. The overall and common goals of the programs are to maintain commercial service in all parts of Sweden and to provide subsidies to firm investments.

Examples of initiatives date back to the beginning of the 1990s, where the organization All Sweden shall live! was started with the aim of stimulating and supporting local development and improving rural policies in Sweden. A new regional development policy was announced by the Swedish parliament in 2001 after passing the bill 2001/02:4 En politik för tillväxt och livskraft $i$ hela landet (A policy for growth and viability for the country as a whole), which specifically focused on maintaining a sustainable service level in all parts of Sweden. As part of the support, the Swedish Consumer Agency (Konsumentverket) got the task to find new 
solutions for improvements of commercial services. For instance, the project Stores in the countryside was one of the projects supported by the Swedish Consumer Agency and implemented by The Rural Service Association (Landsbygdsservice). The project aimed to improve stores in rural areas, for example, by assigning mentors to improve communication between store managers and local authorities, and implement store performance actions, such as store refitting and changes in the distribution of products, improving the technical equipment, and modernization of inventories (Nordregio, 2011). After 2010, several of the projects to improve retailers' situation in rural areas are running under the Rural Development Program [RDP], which receives support from the EU with the main aim of fostering competitiveness to achieve a balanced territorial development of rural economies and communities. Subsidies and investment support in technical equipment are examples of policy tools implemented by the program that support the development of retailers.

While we do not observe if the stores in our sample are part of different development programs, we use the suggested policy tools in these programs to run various policy experiments and to quantify their effectiveness for the development of Swedish retail. We particularly focus on the common goals of these programs to subsidize firm investments and to maintain retail services in all geographic areas.

Data, product variety, and local markets. This paper focuses on Retail sale of new goods in specialized stores (Swedish National Industry (SNI) three-digit code 524). This retail sector includes the following sub-sectors at the five-digit SNI: clothing, footwear and leather goods, furniture and lighting equipment, electrical household appliances and radio and television goods, hardware, paints and glass, books, newspapers and stationery, and specialized stores.

We use two data-sets provided by Statistics Sweden. The first data-set covers detailed annual information about all retail firms in Sweden (census) from 2000 to 2009. The data contain financial statistics of input and output measures, i.e., sales, value-added, the number of employees, capital stock, inventories, cost of products, and investment. Inventories capture the value of products held in stock by the end of each year and are taken from book values (accounting data). Sales are measured in output prices, whereas the cost of products and inventories are measured in input prices (what stores pay to the wholesaler). Because of difficulties in measuring quantity units in retailing (and services) arising from the nature and complexity of the product assort- 
ments, quantity measures of output and inventories are not available in many data-sets such as census data. In retail, we often refer to firms as stores. In our data, a unit of observation is an organization number. ${ }^{12}$ We observe the municipality in which each organization number is physically located. Following previous work on Swedish retail, we use municipalities as local markets (Maican and Orth, 2015; Maican and Orth, 2018a). Therefore, an advantage of our data is that we can exploit local variation and study the impact of competition.

Our second data-set covers store-level information on the number of product categories and their values sold each year across Sweden. To the best of our knowledge, such detailed data on the number of product categories across stores and local markets in services industries have not previously been used in the literature. The data cover all product categories that a store sells on a yearly basis. Unique identification codes allow us to match products perfectly to stores. ${ }^{13}$ To reduce the dimensionality of the product space in the empirical application, we use well-defined product categories to define store products, e.g., shoes for women, shoes for men, and shoes for children. The number of product categories captures the extensive margin of product variety inside a store. Thus, we define product variety as the number of product categories. Data on sales per product category capture the intensive margin of product lines (range) inside a category. Most importantly, the combination of the two data sets allows us to compute product market shares inside a store and a store's market share in a geographic market, which provides rich information related to competition. The mix of product-level and store-level data is novel and, to the best of our knowledge, has not been used in service industries before.

Descriptive statistics and stylized facts. Table 1 shows the median and the interquartile range for the key variables in our data. The median store in our data has approximately 11 million SEK in sales, seven employees, and approximately four product categories. The number of product categories varies between one and 17 in our sample. The five-digit sector median market share is approximately 34-38 percent in a local market, and it is increasing over time. There is an increase in the local concentration over time in our sample, for example, median C4 computed at the five-digit sector increases from 91 to 94 percent.

\footnotetext{
${ }^{12}$ In a few cases in our data, an organization number can consist of more than one physical store (a multi-store) in the same municipality, for which we observe total, not average, inputs and outputs. Multi-store reporting is less than five percent in our sample (Maican and Orth, 2015).

${ }^{13}$ The product data set follows a similar classification system to the one used for the sample data collected on prices and quantities in manufacturing (PRODCOM).
} 
For a better understanding of the relationship between store performance and product variety (extensive and extensive margins), we investigate the evolution of correlations over time in Table 2. The number of product categories (extensive margin) is negatively correlated with sales per cost of goods, which suggests that stores with fewer product categories sell more per unit cost. In addition, the number of product categories is positively correlated with capital stock per employee and the local market share (benefits of economies of scope). These findings suggest that the trade-off between productivity and quality might play a key role in product selection. Capital per employee is positively correlated with the cost of goods per product category (not reported) implying that stores with high technology sell a larger range of products into a product category or sell high-quality products.

On the intensive margins related to product variety, we focus on the average sales per product category and the entropy of product sales. Entropy measures store diversification in sales and is computed for each store $j$ based on the market share of each product category $i$ inside the store, i.e., $E_{j t}=\sum_{i} m s_{i j t} l n\left(m s_{i j t}\right)$ (Bernard et al., 2011). A large measure of entropy suggests that the store focuses on top sales categories. The average sales per product category is positively correlated with measures that affect productivity and shopping quality, such as capital stock per employee and average wage at the store. Stores with sales driven by top products (i.e., large entropy) have high inventory per product category and thus high quality. Stores with high local market shares have low entropy, a large end-of-year inventory, and high labor productivity and capital stock per employee.

Using reduced-form regressions, we investigate the role of market shares, margins and local market concentration for product variety. Table 3 shows evidence of the relationships between a store's product variety and market share, margin and local market concentration using the fixed-effect estimator that controls for store heterogeneity. ${ }^{14}$ The findings show that an increase in local market concentration is associated with fewer product categories, i.e., stores specialize. In addition, stores with large margins have a smaller number of product categories.

Because of the increasing concentration in retail over time, we investigate whether stores with a high market share have high productivity. Table 4 presents reduced-form evidence of the relationship between sales per employee (labor productivity) and stores' market share using an $\operatorname{AR}(1)$ specification. We find a positive association between market share and labor pro-

\footnotetext{
${ }^{14} \mathrm{~A}$ store's margins are proxied using the (net sales - cost of goods)/net sales ratio.
} 
ductivity. This suggests that stores use information about demand to improve productivity. The persistence in labor productivity is approximately 86 percent. While all the reduced-form results might be biased because of the endogeneity of market shares, margins and concentration measures, they help to understand the variation in the data. They also show evidence of the existence and determinants of superstar firms discussed in Autor et al. (2018).

\section{Empirical framework}

This paper uses a framework that incorporates a multi-product sales technology and local market information to study the determinants of economies of scale and scope in retail. The proposed model endogenizes the retailer's choices and underlines the factors behind the recent trends in retail development toward larger stores that offer more product categories, i.e., the utilization of economies of scale and scope.

To generate sales, stores decide the number of products, labor, inventory adjustments, and investments in technology based on the observed information at the beginning of period $t .{ }^{15}$ The multi-product sales technology models economies of scope and is used to form a system of product sales for each store. We use the multi-product technology together with the implications of equilibrium behavior from stores' decisions and local market information to recover the store's revenue productivity and demand shocks. Then, we evaluate the impact of different policies at the store and local market levels on the store's product variety (i.e., extensive margin) and sales per product (i.e., intensive margin).

Multi-product service generating function. Stores use the same service technology to sell their products, and this technology does not depend on the product category. Stores compete in the product market and collect their payoffs. At the beginning of each time period, stores decide whether to exit or to continue operating in the local market. If a store continues, it chooses optimal levels of the number of products, products bought from the wholesaler and the adjustments in inventory before sales, investment in capital/technology, and labor (the number

\footnotetext{
${ }^{15}$ We refer to variety as the number of products produced or sold by a firm. Variety is measured by the number of product categories when there is no data on all products in a category (i.e., product range inside a category). Prices might be difficult to access due to different, e.g., pack sizes or units of measure for retail census data-sets. We do not observed prices in our data. However, a construction of a price index at the product category level will suffer of measurement errors due to different composition of the product goods inside a category across stores.
} 
of employees). ${ }^{16}$

In the case of multi-product, the productivity of one input for a product is not independent of the other products provided by the store, which adds complexity to the store's profit maximization behavior (Hicks, 1946; Mundlak, 1964). This complexity is because of difficulties in aggregating the output, that is, a composite output depends on other things including prices. Most importantly, the modeling framework for multi-product stores is able to explain why stores hold a specific number of products given their resources. We consider that the multi-product service generating function for a store can be written as an implicit function, which assumes separability between inputs and outputs, $F(\mathbf{Q}, \mathbf{V})=G(\mathbf{Q})-H(\mathbf{V})=0$, where $\mathbf{Q}$ is the vector of outputs, and $\mathbf{V}$ is the vector of inputs. The implicit transformation function $F\left(\mathbf{Q}_{j}, \mathbf{V}_{j}\right)=0$ for store $j$ can be described by a transcendental function (generalizes Cobb-Douglas) (Mundlak, 1964; Fuss and McFadden, 1978)

$$
Q_{1 j}^{\tilde{\alpha}_{1}} \times \cdots \times Q_{n p_{j} j}^{\tilde{\alpha}_{n p_{j}}} \exp \left(\tilde{\gamma}_{1} Q_{1 j}+\cdots+\tilde{\gamma}_{n p_{j}} Q_{n p_{j} j}\right)=L_{j}^{\tilde{\beta}_{l}} K_{j}^{\tilde{\beta}_{k}} A_{j}^{\tilde{\beta} a} \exp \left(\tilde{\omega}_{j}\right)
$$

where $n p_{j}$ is the number of products of store $j$; $Q_{i j}$ is the quantity of product $i$ sold by store $j$ $\left(i=1,2, \cdots, n p_{j t}\right) ; L_{j}$ is the number of employees:; $K_{j}$ is the capital stock; $A_{j}$ is the inventory before sales; and $\tilde{\omega}_{j}$ is quantity-based total factor productivity (technical productivity). To reduce the number of parameters when using sales data in empirical applications, Mundlak (1964) suggests the use of aggregation weights $\tilde{\gamma}_{i}=\tilde{\alpha}_{y} P_{i}$, where $P_{i}$ is the price of product $i$ and $\tilde{\alpha}_{y}$ is a parameter to be estimated.

Taking the logarithm in the multi-product function (1) and indexing by time, we obtain the

\footnotetext{
${ }^{16}$ We treat each store as a decision maker. The majority of stores in our sample are single establishments in a local market. We focus on investments in machinery and equipment and refer to this as investments in capital and technology. In retail, technology is embedded in machinery equipment (hardware), which is used to generate sales. We follow the common notation of capital letters for levels and small letters for logs.
} 
following service generating function: ${ }^{17}$

$$
\sum_{i=1}^{n p_{j t}} \tilde{\alpha}_{i} q_{i j t}+\tilde{\alpha}_{y} Y_{j t}=\tilde{\beta}_{l} l_{j t}+\tilde{\beta}_{k} k_{j t}+\tilde{\beta}_{a} a_{j t}+\tilde{\omega}_{j t}+\tilde{u}_{j t}^{p},
$$

where $q_{i j t}$ is the $\log$ of quantity of product $i$ sold by store $j$ in period $t ; Y_{j t}$ is the total sales of store $j$ in period $t ; l_{j t}$ is $\log$ of the number employees; $k_{j t}$ is $\log$ of capital stock; $a_{j t}$ is $\log$ of the sum between the inventory level in the beginning of period $t\left(n_{j t}\right)$ and the products bought during period $t$; and $\tilde{u}_{j t}^{p}$ are i.i.d. remaining service output shocks. The service technology (2) is consistent with the theoretical micro foundations of the multi-product technology frontier and profit maximization. It implies separability in inputs and outputs, and productivity of resources in one product output is not independent of the level of production in other products. The term $\tilde{\alpha}_{y} Y_{j t}$ (output aggregation using sales) together with product output parameters $\tilde{\alpha}_{i}$ plays a key role in profit maximization in the multi-product case. For example, if $\tilde{\alpha}_{y}=0$, i.e., Cobb-Douglas specification in both inputs and outputs, then profit maximization does not hold when producing/selling $n p_{j t}$ products. $^{18}$

In our retail setting, inventories before sales $a_{j t}$ enter as an input of the service generating function since the core activity of retail stores is to buy finished products from wholesalers and resell them to consumers (Bils and Kahn, 2000). ${ }^{19}$ A store's optimal inventory level balances two counteracting forces. Inventories reduce the risk of stock-outs and increase store attractiveness but are costly to adjust and hold in stock. Inventories provide a convenience yield to consumers because they reflect the reduction in shopping cost, i.e., less frequent stock-outs, provision of variety, and other benefits associated with the underlying retail services (Maican and Orth, 2018b). We use the information on the store's inventory demand to recover store-

\footnotetext{
${ }^{17}$ In a companion paper, Maican and Orth (2019) present a general result on the identification of multi-output service generating functions following Mundlak (1964) and discuss the restrictions of the parameters that must be satisfied for profit maximization. We assume that all stores use the same service technology to sell their product categories and that this technology does not depend on the identity of the product category. As discussed in Maican and Orth (2019), this assumption helps to reduce the number of parameters to be estimated. However, it can be relaxed to allow a separate technology for each product when there are sufficient data for all products across markets over a long period.

${ }^{18}$ See Mundlak (1964) and Maican and Orth (2019) discuss the importance of the form of the multi-product function for profit maximization.

${ }^{19}$ See also Humphreys et al. (2001), Iacoviello et al. (2011), and Wen (2011) for an extensive discussion on the differences and the role of input and output inventories. We model inventory as a type of capital that evolves endogenously based on products bought from the wholesaler and adjustments in inventory, and it is characterized by adjustment and holding costs.
} 
specific information on demand that is not observed in the data, i.e., demand shocks (discussed in detail below). ${ }^{20}$

Working with a multi-product setting requires taking into account aggregation over the different products to understand sales technology possibilities. To use the product sales to aggregate over products, we need product prices. In many cases, product prices are not observed, and we use the equilibrium price from a demand equation to model sales. For simplicity of exposition, we assume that consumers have CES preferences over differentiated products and services $i \in\left\{1, \cdots, n p_{j t}\right\}$ inside the store. We exploit the link between a CES demand system and a discrete choice demand system, which allows us to write the consumer choice probability equation from the CES preferences. ${ }^{21}$ Using this relationship, the log of the price of product $i\left(p_{i j t}\right)$ from the consumer choice probability equation is given by $\mathrm{p}_{i j t}=-\frac{1}{\sigma}\left(q_{i j t}-q_{0 t}\right)+\mathbf{x}_{i j t}^{\prime} \frac{\boldsymbol{\beta}_{x}}{\sigma}+\frac{\sigma_{a}}{\sigma} a_{j t}+\frac{1}{\sigma} \tilde{\mu}_{i j t}$, where $\mathbf{x}_{i j t}$ are the observed determinants of the extensive and intensive margins of the utility function when consumers decide whether to buy and how much to buy of the product $i$; $\sigma$ is the elasticity of substitution; $\tilde{\mu}_{i j t}$ are unobserved demand shocks for the econometrician that are not under store control, e.g., unobserved quality for product $i$ in store $j$ in period $t$; and $q_{0 t}$ is the outside option. ${ }^{22}$ The presence of $a_{j t}$ in a demand equation captures the fact that consumers prefer in-stock products to minimize the search cost. The vector $\mathbf{x}_{i j t}$ includes observed product and store characteristics and local market characteristics (for example, population, population density, and income). To simplify the notation, we omit the local market index $m$ when the store index $j$ is present, and we refer to store $j$ in market $m$ (in our data, a store is unique).

We use the service production (2) and the price equation (inverse demand) to obtain the sales generating function at the store level, $y_{i j t}=q_{i j t}+p_{i j t}$ (Maican and Orth, 2019):

$$
y_{i j t}=-\alpha_{y} y_{-i j t}+\left(\beta_{l} l_{j t}+\beta_{k} k_{j t}+\beta_{a} a_{j t}\right)+\beta_{q} y_{m t}+\mathbf{x}_{j t}^{\prime} \boldsymbol{\beta}_{x}+\omega_{j t}+\mu_{j t}+u_{i j t}^{p},
$$

where $y_{i j t}$ is the $\log$ of the sales of product $i$ in store $j$ in market $m$ in period $t ; y_{-i j t}$ is the $\log$ of the sales of products other than product $i$ in store $j$; and $y_{m t}$ measures sales of the outside option captured by the sales of products in a local market $m$ that do not belong to the five-digit subsector of product $i$. By using sales of different products, we are able to reduce the number

\footnotetext{
${ }^{20}$ Having annual data, we do not model stock-outs.

${ }^{21}$ See, e.g., Anderson et al. (1987), Anderson and De Palma (2006), and Dube et al. (2020).

${ }^{22}$ The demand system is similar to the logit discrete choice system, but the price is in logs.
} 
of parameters to be estimated, that is, we estimate only the coefficient of sales of products other than product $i$ at store $j$, i.e., $\alpha_{y}$, and not all coefficients $\alpha_{i}, i=\left\{1, \cdots, n p_{j t}\right\} .{ }^{23}$ The observed and unobserved product characteristics are aggregated at the store level using $\tilde{\alpha}_{i}$ as weights. For example, $\mu_{j t}$ sums all remaining unobserved product demand shock $\mu_{i j t}$ at the store level. ${ }^{24}$ We refer to $\mu_{j t}$ as store $j$ 's specific demand shocks in period $t$. Demand shocks $\mu_{j t}$ measure factors related to product quality, location, checkout speed, the courteousness of store employees, parking, bagging services, and cleanliness. Although we can refer to demand shocks $\mu_{j t}$ as a measure of customer satisfaction and the quality of the shopping in store $j$ in period $t$, to avoid overinterpretation, we continue to refer to them as demand shocks. The evolution of demand shocks $\mu_{j t}$ is not under store $j$ 's control.

Estimating only one coefficient for the other products (i.e., $\alpha_{y}$ ) when controlling for unobserved prices has a cost, that is, we cannot obtain a clean measure of technical productivity $\tilde{\omega}_{i}$ because the coefficients of labor, capital and inventories include demand residuals even if we control for the elasticity of substitution. In fact, unlike manufacturing, it is difficult to define technical productivity in service industries. Therefore, the variable $\omega_{j t}\left(\omega_{j t} \equiv(1-1 / \sigma) \tilde{\omega}_{j t}\right)$ measures revenue (sales) productivity, and we refer to it as simple store productivity in what follows. The productivity measure $\omega_{j t}$ might include sales shocks due to approximations in (3), but all these sales shocks are different from the demand shocks $\mu_{j t}$ that affect consumers' preferences for a store. The evolution of productivity $\omega_{j t}$ is under store $j$ 's control. In other words, we are able to separate productivity shocks $\omega_{j t}$ from store's demand shocks $\mu_{j t}$, which are part of the demand, affect store market share and are not under the store's control. Both productivity $\omega_{j t}$ and demand shocks $\mu_{j t}$ are unobserved by the researcher, but they are known by the stores when making decisions. The vector $\mathbf{x}_{j t}$ sums all observed characteristics at the store and market levels. $u_{i j t}^{p}$ are i.i.d. remaining shocks to sales that are mean independent of all the control variables and store inputs.

The coefficient $\alpha_{y}$ provides information on economies of scope and plays a key role in both the level and persistence of productivity. The new parameters of the multi-product sales generating function (3), i.e., $\beta_{l}, \beta_{k}, \beta_{a}$, are similar to the aggregate sales function at the store (firm)

\footnotetext{
${ }^{23}$ To obtain equation (3), we denote $\tilde{\alpha}_{i} y_{i j t}+\tilde{\alpha}_{y} Y_{i j t} \equiv \alpha_{i} y_{i j t}$ and $\tilde{\alpha}_{i} y_{-i j t}+\tilde{\alpha}_{y} Y_{-i j t} \equiv \alpha_{y} y_{-i j t}$ and normalize $\alpha_{i}=1$. The coefficients are given by $\beta_{q}=1 / \sigma$ and $\beta_{c}=\tilde{\beta}_{c}(1-1 / \sigma)$ where $c \in\{l, k, x, a\}$.

${ }^{24} \mathrm{In}$ fact, $\mu_{j t}$ is a weighting sum of all unobserved product demand shocks at the store level, $\mu_{j t} \equiv$ $(1 / \sigma) \sum_{i=1}^{n p_{j t}} \tilde{\alpha}_{i} \mu_{i j t}$.
} 
level, which allows us to compare them with the previous estimates of single output technology.

Choice of product variety. To obtain stores' sales per product category (intensive margin) and by solving the multi-product technology, we need information on how stores choose the number of product categories (extensive margin) and inputs. Stores know their productivity $\omega_{j t}$ and demand shocks $\mu_{j t}$ when they make their input decisions based on the following dynamic optimization problem given by the Bellman equation (Maican and Orth, 2019):

$$
\begin{aligned}
V\left(\mathbf{s}_{j t}\right)=\max _{n p_{j t}, a_{j t}, l_{j t}, i_{j t}} & {\left[\pi\left(\mathbf{s}_{j t} ; n p_{j t}, a_{j t}, l_{j t}, i_{j t}\right)-c_{l}\left(l_{j t}\right)-c_{n}\left(n p_{j t}, a_{j t}\right)\right.} \\
& \left.-c_{i}\left(i_{j t}, k_{j t}\right)+\beta E\left[V\left(\mathbf{s}_{j t+1}\right) \mid \mathcal{F}_{j t}\right]\right],
\end{aligned}
$$

where $\mathbf{s}_{j t}=\left(\omega_{j t}, \mu_{j t}, k_{j t}, n_{j t}, n p_{j t-1}, w_{j t}, y_{m t}, \mathbf{x}_{m t}\right)$ is the state variable; $w_{j t}$ is log of average wage at store $j ; \pi\left(\mathbf{s}_{j t}\right)$ is the profit function, which is a function of the store's total sales $y_{j t} ; c_{l}\left(l_{j t}\right)$ is the labor cost; $c_{n}\left(n p_{j t}, a_{j t}\right)$ is the adjustment cost in product categories, which is increasing in inventory in the beginning of period $n_{j t} ;{ }^{25} c_{i}\left(i_{j t}, k_{j t}\right)$ is the investment cost of new capital (equipment), which is increasing in investment choice $i_{j t}$ and decreasing in current capital stock $k_{j t}$ for each fixed $i_{j t} ;^{26} \beta$ is a store's discount factor; and $\mathcal{F}_{j t}$ represents the information available at time $t$.

The dynamic equation (4) is a complex optimization problem and to solve it, we need to fully model the cost structure at the store level. In this paper, we follow Olley and Pakes (1996) and Bajari et al. (2007), who instead of directly solving the optimization problem (4), use the nonparametric policy functions for identification and estimation. ${ }^{27}$ The policy functions are functions of the store's state variables and capture complex decisions by stores, where current choices affect the future development of the store. The store's optimal number of product categories is $n p_{j t}=n p_{t}\left(\mathbf{s}_{j t}\right)$, inventory demand is $a_{j t}=f_{t}\left(\mathbf{s}_{j t}\right)$, labor demand is $l_{j t}=l_{t}\left(\mathbf{s}_{j t}\right)$, and investment is $i_{j t}=i_{t}\left(\mathbf{s}_{j t}\right)$. In the empirical implementation of the policy experiments, we

\footnotetext{
${ }^{25}$ The evolution and adjustments in inventory follow the previous literature (e.g., Coen-Pirani, 2004). The inventory level at the beginning of period $t+1$ evolves according to $N_{j t+1}=A_{j t}-Y_{j t}$, where $A_{j t}$ is the adjusted inventory before sales, i.e., the inventory in the beginning of the period $N_{j t}$ adjusted with the products bought in period $t$, and $Y_{j t}$ is store-level sales. That is, $N_{t+1}$ captures inventory in the beginning of period $t+1$ (or end of period $t$ ) after sales in period $t$ are realized.

${ }^{26}$ Capital stock is a dynamic input that accumulates according to $K_{j t+1}=\left(1-\delta_{k}\right) K_{j t}+I_{j t}$, where $\delta_{k}$ is the depreciation rate. The investment $I_{j t}$ in machinery and equipment is chosen in period $t$ and affects the store in period $t+1$.

${ }^{27}$ Studying the impact on the entry regulation on product variety, Maican and Orth (2019) use value function approximation techniques to numerically solve the Bellman equation (see also Ryan, 2012; Sweeting, 2013; Maican et al., 2018).
} 
use the estimated policy functions to calculate the optimal product categories and evaluate the impact of economic policies on the extensive and intensive product margins.

Learning from demand. Store productivity $\omega_{j t}$ and demand shocks $\mu_{j t}$ are correlated over time, and they are not observed by the researcher. We assume that the demand shocks $\mu_{j t}$ follow a nonlinear $\mathrm{AR}(1)$ process

$$
\mu_{j t}=\gamma_{0}^{\mu}+\gamma_{1}^{\mu} \mu_{j t-1}+\gamma_{2}^{\mu}\left(\mu_{j t-1}\right)^{2}+\gamma_{3}^{\mu}\left(\mu_{j t-1}\right)^{3}+\eta_{j t}
$$

Our model allows demand shocks that can be associated with the quality of the shopping experience to influence store productivity.

In our setting, demand shocks can influence store productivity in at least two ways. The first is through productivity gains within stores that arise, for instance, because stores obtain opportunities to analyze information from consumers and use it to improve the shopping process and inventory management. For example, store employees are responsible for many small improvements that improve the sales process inside the store (i.e., innovations on the floor). The second channel is through a selection effect from the exit of low-productivity stores. ${ }^{28}$ Thus, productivity changes as a result of changes in received demand shocks, although we also recognize that it is plausible that stores engage in other active efforts to increase their productivity. Our model quantifies the overall effect of demand shocks on productivity rather than modeling all possible sources of productivity improvement. Therefore, store productivity $\omega_{j t}$ follows an endogenous nonlinear $\operatorname{AR}(1)$ process where previous productivity $\omega_{j t-1}$ and demand shocks $\mu_{j t-1}$ affect current productivity

$$
\begin{aligned}
\omega_{j t}= & \gamma_{0}^{\omega}+\gamma_{1}^{\omega} \omega_{j t-1}+\gamma_{2}^{\omega}\left(\omega_{j t-1}\right)^{2}+\gamma_{3}^{\omega}\left(\omega_{j t-1}\right)^{3}+\gamma_{4}^{\omega} \mu_{j t-1} \\
& +\gamma_{5}^{\omega} \omega_{j t-1} \times \mu_{j t-1}+\xi_{j t} .
\end{aligned}
$$

$\eta_{j t}$ and $\xi_{j t}$ are shocks to demand and productivity, respectively, which are mean-independent of all information known at $t-1$.

Market shares and demand shocks. The demand shocks $\mu_{j t}$ affect consumers' choices and, therefore, the store's market share. To recover information about them from an aggregate demand system at the store level that defines the consumer's utility of choosing store $j$, we need

\footnotetext{
${ }^{28}$ The selection effect is less important in our empirical setting even if we allow exit in the theoretical framework. This is because of we observe a few exits in our data sample.
} 
to define a product basket and construct a price index for this product basket. It is difficult to observe/obtain accurate price and quantity data in most services industries where scanner data are not available. ${ }^{29}$ However, this does not limit our ability to recover the demand shocks $\mu_{j t}$ using the recent developments from the product function literature, which suggests the use of an output process and an input process that are observed to control for unobservables (Ackerberg et al., 2007). In our case, an informative output for demand shocks and product sales should be related to the store's market share. The input is the inventory before the sales, which incorporates information about $\mu_{j t}$. We consider that the ratio between store market share and market share of outside option is a function of store and market characteristics $\boldsymbol{\delta}_{j t}$ (they can include $\mathbf{x}_{m t}$ ) and $\mu_{j t}$

$$
\ln \left(m s_{j t}\right)-\ln \left(m s_{0 t}\right)=\boldsymbol{\delta}_{j t} \boldsymbol{\rho}+\mu_{j t}+\nu_{j t}
$$

where $m s_{j t}$ is the market share of store $j$ in local market $m$ in period $t$ computed at the five-digit industry level; $m s_{0 t}$ is the outside option, i.e., the market share of other stores in market $m$; and $\nu_{j t}$ is an error term mean independent of all the controls. In the empirical implementation, $\boldsymbol{\delta}_{j t} \boldsymbol{\rho}=\rho_{n p} n p_{j t}+\rho_{i n c, 1} i n c_{m t}+\rho_{i n c, 2} i n c_{m t}^{2}$, where $n p_{j t}$ is the number of product categories $n p_{j t}$ and $i n c_{m t}$ is the log of average income in the local market. ${ }^{30}$

Sales are a commonly used output measure in services and depend on both demand and supply factors. In our model, sales depend on both the store's demand shocks $\mu_{j t}$ and productivity $\omega_{j t}$, whereas a store's market share depends only on $\mu_{j t}$. In other words, the market share index function (7) and the sales generating function (3) are linked through the demand shocks $\mu_{j t}$, which ensure consistency and identification of the model. Furthermore, because the sales generating function (3) controls for capital stock $k_{j t}$ and inventory $a_{j t}$, they are not part of $\mu_{j t}$, and we do not need to control for them in the market share equation. ${ }^{31}$ The number of product categories $n p_{j t}$ is part of $a_{j t}$, but $a_{j t}$ includes additional information, such as the volume of each

\footnotetext{
${ }^{29}$ Furthermore, given that labor and capital measures are recorded annual, even if the data on prices is available, the construction of annual price index and product basket is complex.

${ }^{30}$ The equation (7) is not a logit demand specification. It does not include the price, but it includes product categories and residuals $\nu_{j t}$. Note that we cannot use the common nonparametric inversion strategy from discrete choice literature to recover $\mu_{j t}$. This is because $\mu_{j t}$ is also part of supply side and the presence of remaining shocks $\nu_{j t}$.

${ }^{31}$ Even if we control for capital stock $k_{j t}$ and inventory $a_{j t}$ in the market share equation, we cannot separately identify their effects on demand and supply, i.e., we identify the net effect.
} 
product, and the products are aggregated based on monetary value. Equations (3) and (7) are used in counterfactuals to predict store sales, total sales of outside option, and, therefore, total sales in a local market. In detail, equations (3) and (7) form two systems of equations, that is, one at the store level (capturing sales per product) and one at the local market (capturing market shares), which can be used to predict changes in sales in policy experiments.

Identification and estimation. The multi-product approach uses inputs at the firm/establishment level, and therefore, the identification and estimation are based on the well-established two-step methods in the production function literature (Ackerberg et al., 2007). Our model consists of two equations (multi-product sales and market share) and two unobservables (productivity and demand shocks), where one of the equations includes one of them. The core of the identification of such a system of equations is discussed in detail by Ackerberg et al. (2007) (Section 2.4). ${ }^{32}$ The inputs, outputs and the number of product categories are endogenous, i.e., they are correlated with $\omega_{j t}$ and $\mu_{j t}$. The identification and estimation follow Olley and Pakes (1996) and the subsequent literature and include the estimation of the Markov processes for $\omega_{j t}$ and $\mu_{j t}$. We estimate $\theta=\left(\beta_{l}, \beta_{k}, \beta_{a}, \beta_{x}, \alpha_{y}, \beta_{q}, \rho_{n p}, \rho_{i n c, 1}, \rho_{i n c, 2}\right)$ using a two-step estimator. In contrast to Olley and Pakes (1996), we have two unobservables to recover instead of one (see also Maican and Orth, 2019). We use the store's labor demand function to recover productivity (Doraszelski and Jaumandreu, 2013; Maican and Orth, 2017). ${ }^{33}$ We use the store's demand for inventory $a_{j t}$ to recover the demand shocks $\mu_{j t}$. The equations that are used in the estimation are the multi-product sales function (3), market share equation (7) and productivity and demand shocks (6) and (5). In the first step, we recover $\omega_{j t}$ and $\mu_{j t}$ using polynomial expansion of order three in variables of the inverse labor and inventory demand functions in equations (3) and (7). In the second step, we use the productivity (6) and demand shock (5) processes to obtain the shocks $\left(\xi_{j t}+u_{i j t}\right)$ and $\left(\eta_{j t}+\nu_{j t}\right)$ as functions of parameters $\theta$. The online Appendix A provides additional details on the estimation and identification.

Because $\omega_{j t}$ and $\mu_{j t}$ are functions of coefficients of the service generating function and market shares, we can identify $\theta$ coefficients using moment conditions based on $\left(\xi_{j t}+u_{i j t}\right)$ and $\left(\eta_{j t}+\nu_{j t}\right)$ and the generalized method of moments (GMM) estimator. ${ }^{34}$ To identify $\theta$, the

\footnotetext{
${ }^{32}$ See also Matzkin (2008).

${ }^{33}$ Levinsohn and Petrin (2003) use intermediate inputs to recover productivity.

${ }^{34}$ Our empirical results remain robust using moment conditions based on $\xi_{j t}$ and $\eta_{j t}$ to identify parameters $\beta_{l}, \beta_{k}, \beta_{a}, \beta_{x}, \beta_{q}, \rho_{n p}, \rho_{i n c, 1}$, and $\rho_{i n c, 2}$ in the empirical application.
} 
following moment conditions are used, i.e., $E\left[\xi_{j t}+u_{i j t} \mid y_{-i j t-1}, l_{j t-1}, k_{j t-1}, a_{j t-1}, \mathbf{x}_{m t-1}\right]=0$ and $E\left[\eta_{j t}+\nu_{j t} \mid n p_{j t-1}, i n c_{m t-1}, i n c_{j t-1}^{2}\right]=0 .{ }^{35}$ That is, we use that the remaining shocks are not correlated with the previous variables to form the moments. ${ }^{36}$

The parameters of the inputs in the sales function $\left(\beta_{l}, \beta_{k}, \beta_{a}\right)$ are identified using $l_{j t-1}, k_{j t-1}$, $a_{j t-1}$ as instruments, i.e., we use that the current remaining productivity and sales shocks are not correlated with previous inputs to form moment conditions. The economies of scope parameter $\alpha_{y}$ is identified using $y_{-i j t-1}$ as an instrument, i.e., we use that previous output is not correlated with current remaining sales and productivity shocks. Even if Monte-Carlo experiments show the robustness of the identification of the scope parameter using previous output, we also discuss below an alternative estimator that is computationally more demanding. That previous local market characteristics $\mathbf{x}_{m t-1}$ are not correlated with current sales and productivity shocks allows us to identify $\beta_{x}$ (in general, $\mathbf{x}_{m t}$ can also be used as instruments because market characteristics are exogenous). Finally, the coefficients of the market share equation are identified using that the sum of the remaining demand shocks $\left(\eta_{j t}+\nu_{j t}\right)$ are not correlated with the previous number of product categories and income. It is important to note that having the parameters of the multi-product sales generating function and the market share equation, we estimate the parameters of the Markov processes. The parameters $\boldsymbol{\theta}$ are estimated by minimizing the GMM objective function

$$
\min _{\boldsymbol{\theta}} Q_{N}=\left[\frac{1}{N} W^{\prime} v(\boldsymbol{\theta})\right]^{\prime} A\left[\frac{1}{N} W^{\prime} v(\boldsymbol{\theta})\right]
$$

where $v_{j t}=\left(\xi_{j t}+u_{i j t}, \eta_{j t}+\nu_{j t}\right)^{\prime}, W$ is the matrix of instruments, and $A$ is the weighting matrix defined as $A=\left[\frac{1}{N} W^{\prime} v(\boldsymbol{\theta}) v^{\prime}(\boldsymbol{\theta}) W\right]^{-1} \cdot 37$

Alternative identification for economies of scope parameters. We can use an alternative identification strategy for the economies of scope parameter. Instead of using the previous output of other products as an instrument, we can solve the system of output equations for

\footnotetext{
${ }^{35}$ Using Monte-Carlo simulations, Maican and Orth (2019) show identification of the multi-product sales technology using labor demand to proxy for productivity. They also show that the product sales system of equations at the store level (non-linear) has a unique solution, which implies that we can compute product sales if we have information on inputs, productivity and demand shocks.

${ }^{36}$ Ackerberg et al. (2007) and Wooldridge (2009) provide an extensive discussion on using previous variables as instruments in a two-step control function approach when estimating production functions.

${ }^{37}$ Standard errors are computed according to Ackerberg et al. (2012).
} 
each store, i.e., as we do in the counterfactual experiments. In other words, we fully endogenize product sales in the estimation. However, this estimator is computationally demanding because we have to solve the system of equations for each store-year observation and a new set of model parameters using fixed-point iteration. As mentioned above, Monte Carlo experiments show no main advantages of this alternative estimator over the above IV identification strategy when stores use the same sales technology for their products.

Alternative demand specifications. While our model is rich on the supply side, we acknowledge that the CES preferences are restrictive. However, the form of the multi-product sales generating function (3) is also consistent with a demand specification that allows for rich substitution patterns, e.g., a constant expenditure specification in an aggregate nested logit model where price enters in log form. This is because in a constant expenditure specification, we use the volume of sales for each product category, which allows us to aggregate products when integrating it with the multi-product function (2). ${ }^{38}$ In a nested demand model, consumers choose stores and then products within a store. In this case, the output and input parameters will depend on the nest(s) parameter(s). In other words, the scope parameter $\alpha_{y}$ includes information about product correlation in the nests at the store level. Because we do not focus on a specific product category in the empirical application (e.g., shoes or yogurt) and have high heterogeneity on the supply side in the data, in what follows, we use a simple demand specification. Most importantly, our main empirical results are not driven by the demand assumption and are supported by various simple descriptives and reduced-form specifications (see Section 2).

\section{Results}

This section presents the empirical results. First, we discuss the results of the estimated multiproduct sales generating function, which include estimates of store productivity and demand shocks and how they evolve over time. ${ }^{39}$ Second, we examine the determinants of stores' opti-

\footnotetext{
${ }^{38}$ All technical derivations are available from authors upon request. Unlike the discrete choice specification, a constant expenditure specification allows consumers to buy more than one product (Verboven, 1996; Anderson and De Palma, 2006)

${ }^{39}$ To allow for comparisons across specifications, we show the results using the two-step estimator where coefficients are adjusted for the elasticity of substitution $\sigma$ and the coefficient of other product categories inside the store $\tilde{\alpha}_{y}$.
} 
mal choices of the number of product categories and inventory per product, which are functions of the state variables. We also discuss the drivers of labor, inventory, and investment demand functions. Our aim is to explore the heterogeneity in store productivity and demand shocks and their role in explaining economies of scope and performance across retail stores.

Service generating function estimates. Table 5 shows the estimates of the multi-product sales generating function (equation (3)) by the ordinary least squares (OLS) estimator and the nonparametric two-step estimator presented in Section 2. The two-step estimator controls for the endogeneity of store input choices (i.e., simultaneity) and allows us to identify store productivity separately from shocks to market share. By using the two-step estimator, the coefficients of labor and inventories decrease from 0.786 (OLS) to 0.558 and from 1.036 (OLS) to 0.493, respectively. The coefficient of capital increases from 0.059 (OLS) to 0.283 (the two-step estimator). These changes in the estimates are in line with the production function literature following Olley and Pakes (1996), which suggests an upper bias for the coefficients of labor and inventories when omitting to control for the correlation between inputs and productivity.

The estimated elasticity of demand for product substitution is 4.63 . There is clear evidence of sales cannibalization and competition for limited shelf space among products in a store. Sales of a product category decrease when sales in other product categories increase. With the same resources, a 1 percent increase in sales of a product category decreases sales of other product categories by 0.856 percent. This finding is consistent with the profit maximization behavior of multi-product firms (see Mundlak, 1964; Maican and Orth, 2019). The coefficient of a store's other product categories influences the input coefficients, which affect the productivity measure. Our estimates also show that stores in markets with high population and population density sell more in each product category (i.e., demand effect).

The results from the market share equation (7) clearly show that a store's market share increases in product variety $(0.213)$. In other words, a wider span of products increases the market share. The magnitude is sizable. For example, a store with a 30 percent local market share increases its market share to 35 percent by adding one more product category. Income has a positive effect on consumers' utility function and, therefore, on a store's market share.

Productivity and demand shocks. The heterogeneity of store productivity and demand shocks is informative because it drives the heterogeneity in sales across stores. Using the esti- 
mated parameters from the sales generating function, we recover productivity $\omega_{j t}$ and specific demand shocks $\mu_{j t}$ for each store and year. Store demand shocks $\mu_{j t}$ have a larger variance than productivity $\omega_{j t}$. For productivity, a store in the 75 th percentile has 27 percent greater productivity than a store in the 25 th percentile. However, the store's demand shocks are approximately 50 percent higher for a store in the 75 th percentile than for a store in the 25th percentile.

Table 6 shows the estimates of the processes for store productivity $\omega_{j t}$ and demand shocks $\mu_{j t}$, i.e., equations (6) and (5). The persistence of the productivity process (0.85) is lower than the persistence of the demand shocks (0.92). The magnitude of the persistence in productivity is similar to the findings in other studies in the productivity literature (e.g., Doraszelski and Jaumandreu, 2013 - manufacturing; Maican and Orth, 2017 - retail).

In our model, demand shocks can affect store productivity, and the size of the impact depends on the level of store productivity. The results in Table 6 show that we reject the null hypothesis that the coefficients of $\mu_{j t}$ in the productivity process are equal to zero ( $p$-value $\left.=0.000\right)$. The demand shocks have a positive impact on productivity, i.e., a one percent increase in $\mu_{j t}$ raises productivity by 0.013 percent on average. This finding suggests that stores use information from consumers' choice of products and stores to improve productivity, that is, learning from managing demand. For example, stores with high demand shocks have skilled and service-minded employees who help consumers during the shopping process. These high-ability employees use information from consumers to create appealing innovations that shift store productivity.

\subsection{Product variety, demand for inputs, and market share}

The solution of the dynamic programming at the store level given by the Bellman equation states that the store's choices such as the number of products, labor, inventory, and investment are functions of the state variables. In our case, the state variables that are used to decide optimal choices are productivity $\left(\omega_{j t}\right)$, demand shocks $\left(\mu_{j t}\right)$, previous capital $\left(k_{j t-1}\right)$, inventories at the beginning of the period $\left(n_{j t}\right)$, and local market characteristics $\left(\mathbf{x}_{j t}\right)$.

Product variety. To analyze the determinants of economies of scope, Table 7 shows the estimates of a store's product variety and diversification as functions of the state variables using a 
linear specification that controls for store fixed-effects. The changes in the number of product categories capture stores' adjustments in the extensive margin.

Productivity improvements allow stores to offer a wider product variety. The results show that a 10 percent increase in productivity yields a 3 percent increase in the number of product categories. Stores that invest in technology have more product categories; for example, to add an additional product category, an average store needs an approximately 3 percent increase in the stock of technology.

We find that stores with high demand shocks have a lower number of product categories. On average, a 10 percent increase in demand shocks reduces the number of product categories by 0.4 percent. Therefore, we find evidence of specialization for stores with high demand shocks, that is, it is costly for stores to keep the same quality and offer many product categories (diseconomies of scope). Stores with a large inventory at the end of the year reduce their product categories.

To evaluate the adjustments in intensive margins, we use two measures of store diversification. The first measure is the Herfindahl index (HHI) calculated based on sales of product categories inside the store. The second measure of diversification is the entropy of product sales that measures the extent to which a store's product sales are skewed toward the largest (main) products rather than the smallest.

Table 7 shows key results for store diversification, i.e., how stores react in the intensive margin to changes in store and market primitives. A one percent increase in productivity yields a drop of 7 percent in HHI inside the store, that is, a lower concentration inside the store. Investments in technology also reduce concentration inside the store. An increase in the stock of technology by one percent decreases concentration by 2 percent. On the other hand, an increase in demand shocks increases concentration, which is consistent with the results from the extensive margin.

The findings on entropy show the importance of the trade-off between productivity and demand shocks for the diversification inside a store. Highly productive stores have lower entropy in product sales, which implies higher sales across all product categories. That is, the entropy decreases by approximately 15 percent when productivity increases by one percent. In contrast, an increase in demand shocks by one percent raises entropy by 2 percent, which suggests that 
stores with high demand shocks focus on their top-selling products. The results also show that stores with large end-of-year inventories have large entropy. In other words, stores characterized by top selling products have high inventory, which helps them avoid stock-outs.

Determinants of inventory per product category. Table 8 shows the determinants of average inventory per product before sales are realized $\left(\log \left(A_{j t} / n p_{j t}\right)\right)$ and average inventory per product after sales are realized $\left(\log \left(N_{j t+1} / n p_{j t}\right)\right)$. Higher productivity and demand shocks yields higher inventory per product category before sales, that is, higher demand for inventory. A one percent increase in store productivity (demand shocks) shifts average demand for inventory per product category by about 0.05 percent (0.06 percent). More productive stores have lower inventory per product category after sales are realized. That is, stores that sell more of a product due to their high productivity remain with less inventory per product category after sales are realized. A 10 percent increase in productivity is associated with a 1.2 percent lower end-of-period inventory per product category. Stores with higher demand shocks have higher inventory per product category after sales are realized, which suggests that they eliminate stock-outs.

Market share. Table 8 also provides reduced-form information on the determinants of a store's local market share. ${ }^{40}$ Improvements in productivity and large demand shocks yield a higher market share to stores in local markets. Productivity increases a store's market share substantially more than large demand shocks, i.e., 0.16 versus 0.01 percent. The positive effect of productivity and demand shocks on market share comes from two channels. First, stores that increase their productivity offer more products and sell more of each product. Second, stores with high demand shocks focus on increasing sales of top products. Taken together, stores with higher productivity and higher demand shocks achieve a higher market share.

The determinants of the demand for investment in technology and inputs. Table 9 shows the estimates of the policy functions for investment demand in technology, labor demand, and total inventory demand before sales as functions of the state variables. Understanding these estimates plays a key role in studying stores' decisions over time. Panel A shows the linear specifications of the determinants of the policy functions controlling for store fixed effects. Panel $\mathrm{B}$ shows the prediction of the observed data using b-spline approximation and OLS estimator.

\footnotetext{
${ }^{40}$ The number of product categories is a function of state variables, and thus, we can write store's market share as function of the state variables.
} 
This specification is consistent with the nonlinear propriety of policy functions from solving the Bellman equation. For all policy functions, b-spline approximations provide a good prediction of the observed data.

The findings in Panel A show that stores with high productivity and demand shocks invest more in technology. This result is consistent with the store's dynamic programming property used for identification in Olley and Pakes' framework, i.e., the optimal investment demand increases with productivity. ${ }^{41}$ A 10 percent increase in productivity increases the demand for investment by 2.4 percent on average. Demand shocks also increase a store's optimal investments. A 10 percent increase in demand shocks increases investments by 1 percent. These findings are consistent with the positively correlated trends of inventories and investments in new technology (Maican and Orth, 2018b).

In our model, labor demand plays a key role as a proxy variable in recovering productivity and demand shocks. Most importantly, industry facts emphasize that consumers' shopping experience (part of demand shocks) depends on the employees inside the store. We find that the number of employees is increasing in productivity and demand shocks. As we expect, the impact of productivity on labor demand is larger than that of demand shocks. Furthermore, stores in markets with a large population and high income have more employees.

Stores with high productivity and demand shocks have high inventories $a_{j t}$. Inventory increases substantially more from productivity than from demand shocks. A 3.3 percent increase in inventory before sales $\left(a_{j t}\right)$ is the optimal response to a 10 percent increase in store productivity. The corresponding increase in inventory from a 10 percent increase in demand shocks is 0.1 percent. Store productivity thus plays a more important role in inventory than demand shocks. ${ }^{42}$ As expected, stores that have large capital stock and that are located in markets with high population density have higher inventories.

Summary of the main results. Our estimates of optimal decisions suggest that productivity improvements bring an increase in the flow of products to consumers and allow stores to manage a wider product variety. Productivity as a main driver of product variety is closely linked to the

\footnotetext{
${ }^{41}$ In this paper, investments in machinery and equipment are associated with investments in technology. For example, a new refrigerator includes innovations in both design and technology, which saves space and costs and allows more products to be exposed efficiently.

${ }^{42}$ Because higher productivity and demand shocks increase a store's market power, these findings are consistent with Amihud and Mendelson (1989), who show that firms with greater market power hold more inventories and have higher volatility in inventories.
} 
work by Holmes (2001). ${ }^{43}$ High demand shocks, on the other hand, promotes specialization on fewer product categories. We show that there are trade-offs between productivity and demand shocks that are important for stores to account for when deciding the optimal product mix in the store.

\subsection{Policy experiments}

We use the estimated model to conduct four sets of policy experiments. The experiments highlight determinants of economies of scope in retail and differences between rural and urban markets. We compare stores' outcomes before and after a hypothetical change, focusing on incumbents. Our analysis explores the short-run changes in the intensive and extensive product margins, market shares and concentration. Consumers can benefit from more variety and high quality shopping (part of demand shocks). The sign and size of the changes in stores' optimal decisions and outcomes from a counterfactual experiment are theoretically ambiguous and depend on the scope parameter (i.e., economies of scope) and the store's primitives productivity and demand shocks.

The first set of policy experiments $\left(C F_{1}\right.$ and $\left.C F_{2}\right)$ explores the role of economies of scope and investment in technology in driving sales per product. The second set of experiments $\left(C F_{3}\right.$ and $C F_{4}$ ) emphasizes the benefits of maintaining high productivity and demand shocks over time and their trade-off under uncertainty. The third set of policies $\left(C F_{5}\right.$ and $\left.C F_{6}\right)$ analyzes the role of demand in local markets. Finally, the fourth set of experiments $\left(C F_{7}, C F_{8}\right.$ and $\left.C F_{9}\right)$ focuses on how learning from demand information can improve productivity inside the store, e.g., produce innovations on the floor using demand information.

We use the policy functions to calculate the number of product categories, labor and inventory demand after the policy change. ${ }^{44}$ Then, we solve two systems of equations, i.e., the

\footnotetext{
${ }^{43}$ The sales might decrease in the short-run with the adoption of a new technology, but increase in the long-run because consumers get used with the new technology.

${ }^{44}$ We use the estimated Markov processes to predict the changes in productivity and demand shocks, which affect the choice of product variety and input demand. We estimate the policy functions using a b-splines polynomial expansion in the state variables (Bajari et al., 2007; Ryan, 2012). We only predict the changes in the variables inside the sample. The number of product categories (count variable) is predicted using a negative binomial regression. We report the changes based on 100 simulations (note that productivity and demand shocks are stochastic).
} 
multi-product technology and the market share index function, to calculate the new sales per product category, total sales and market shares. First, we solve the system of multi-product sales equations for each store using a fixed-point iteration algorithm to obtain sales per product category and store-level sales (see Appendix B). Second, for each local market, we solve the market share system to obtain stores' market shares. Third, using the recomputed sales and market shares for stores in the data, we calculate sales and market share of the outside option and local concentration measures such as HHI. ${ }^{45}$

Development in rural and urban markets. The policy experiments focus on changes in urban and rural markets. A goal for policy makers in many countries is to minimize the discrepancies between rural and urban markets. In Sweden, the population in rural markets has decreased by two-thirds since 1985 (Statistics Sweden). This has led to weaker purchasing power and tax income and to lower service level over time. Average store-level sales are 10 percent lower in rural markets, whereas employment is 20 percent lower and the capital stock is about half. For this aim, the Swedish government has implemented several policies in regional development programs, e.g., investment in fast internet and subsidies to investments. To gain knowledge regarding how to design policies that improve the retail landscape in rural areas, we explore differences between rural and urban markets.

\subsubsection{Economies of scope and investments in technology}

The main advantage of our multi-product framework is that it provides the estimated degree of economies of scope inside the store (parameter $\alpha_{y}$ ). The experiment $C F_{1}$ in Table 10 explores the basic benefits of improving economies of scope in rural and urban markets. We implement this semicounterfactual $C F_{1}$ as a fifteen percent decrease in the value of $\alpha_{y}$ keeping the same number of product categories. The median gain in stores' sales and sales per product is 14 percent in rural markets and 12 percent in urban markets. This means a sales increase being 2 percentage points higher in rural than in urban markets when improving economies of scope. This finding shows the importance of improving economies of scope in rural markets to raise

\footnotetext{
${ }^{45}$ We have an adjusted measure of HHI because our model does not endogenize entry and exit of stores. Therefore, our HHI measure is upper biased because it assumes that sales of the outside option are obtained from one store. However, we are interested in the sign of changes in HHI. We find no sign differences when computing the changes in HHI using only stores in the sample and HHI that includes outside sales.
} 
sales per product.

The policy experiment $C F_{2}$ in Table 10 quantifies the short-run impact of technology on intensive and extensive product margins. We assume an exogenous increase in capital stock (machinery and equipment) by thirty percent for all stores. This exogenous increase in capital stock can be seen as an investment subsidy to all stores where the level of subsidy depends on the current level of technology stock. ${ }^{46}$ In rural markets, many Swedish stores have received support through regional development programs to increase their technology stock (Nordregio, 2011). We find that the median increase in the number of product categories is approximately 2 percent, which benefits consumers. Sales per product category also increase by approximately 2 percent, whereas store-level sales increase by 3-4 percent. Interestingly, the increase in sales is approximately 1.5 percentage points higher in urban than in rural markets. Store's market share and local market HHI increase in both markets (the increases are slightly larger in rural markets). We also find that the increase in technology stock induces substitution between labor and capital and better management with inventory, especially in rural markets.

In summary, investments in technology for all stores have positive effects on incumbents' intensive and extensive margins. However, the increase in sales for all stores might raise local market concentration because high-productivity or high-demand stores benefit more from a proportional increase in the stock of technology.

\subsubsection{Trade-offs under uncertainty: Benefits of maintaining productivity and de- mand levels}

Our framework models uncertainty in both productivity and demand shocks, which are stochastic processes. The policy experiments $C F_{3}$ and $C F_{4}$ in Table 11 show the impact of improving the persistence of the store's demand shocks and productivity. This allows for a better understanding of the consequences of degradation in these key primitives, which can have negative consequences for stores if there are no resources to invest in technology. We implement $C F_{3}$ by a five percent increase in the coefficient of the term $\mu_{j t-1}$ in the demand shocks process. In $C F_{4}$, we also add a five percent increase in the coefficient of the term $\omega_{j t-1}$ in the productivity

\footnotetext{
${ }^{46}$ The impact of capital stock on sales remains robust when endogenizing the change in the capital stock using the estimated investment policy function.
} 
process.

The gains from a higher persistence in demand shocks drive specialization where stores sell fewer product categories and continue to receive high demand shocks. Our findings show that store demand shocks increase by 6 percent in rural markets and by 13 percent in urban markets, that is, the demand shock gain is approximately double in urban markets than in rural markets. When demand shocks increase, the number of product categories falls by 1 percent, whereas labor and inventories rise by 2-4 percent. The median sales per product category and store-level sales increase by 2-3 percent, whereas the market share increases slightly less in both markets. If higher demand shocks are associated with the quality of shopping, then the quality of shopping outweighs the decline in the number of product categories, suggesting that consumers benefit up to two times more in urban than in rural markets. Hence, consumers in urban markets benefit relatively more from specialization and demand improvements than consumers in rural markets.

Higher persistence in both productivity and demand shocks shows clear evidence of a mechanism where productivity improvements lead to considerably higher sales and a wider variety of goods that benefit consumers. The number of product categories increases by $4-5$ percent in both markets. The median sales per product category and store-level sales increase by 10 percent and 14 percent, respectively. The difference in the growth in sales between the two types of markets is reduced, which shows the critical role of improving productivity in rural markets. The market share increases only slightly more than in $C F_{3}$. Consumers benefit substantially from the productivity channel due to the increase in variety and quality of shopping.

\subsubsection{Increase in local market demand}

The policy experiments $C F_{5}$ and $C F_{6}$ in Table 12 investigate the impact of an exogenous increase in aggregate local market demand. We assess a thirty percent increase in average income and population in local markets and assume no changes in store productivity, demand shocks, and technology stock. Incumbents respond differently in their input choices to a higher local market demand depending on their productivity and demand shocks. This drives differences between stores and between rural and urban markets. 
The findings in $C F_{5}$ show that a rise in average income reduces the number of product categories by 2.5 percent. As a result, median sales per product increase in both markets. This suggests that an exogenous increase in market income influences both the intensive and the extensive product margins, stimulating stores to specialize on fewer products. ${ }^{47}$ Median store-level sales decrease by 1 percent in rural markets and by 2 percent in urban markets. Specialization is thus more pronounced in urban than in rural markets. The dispersion in changes in store-level sales yields an increase in median market share and HHI. That an increase in income results in lower labor demand and higher inventory before sales confirms the fact that stores specialize in fewer product categories in markets with higher purchasing power. This is because consumers with higher income become more sophisticated and prefer higher quality. It is also because stores face a higher cost with employment and therefore reduce labor. ${ }^{48}$

Experiment $C F_{6}$ quantifies the impact of an increase in the local market population. The results in Table 12 show that a larger local market size decreases incumbents' number of product categories by 3.5 percent and increases sales per product category by $4-5$ percent (median), i.e., stores specialize. ${ }^{49}$ Store-level sales increase from a larger population but not from a higher income in rural markets, where demand for a product might be limited. Policies that raise aggregate demand are important for increasing store-level sales in rural regions. When increasing income, consumers can choose products/stores with higher quality. Additionally, the importance of aggregate demand is shown by a more substantial increase in labor and inventory demand in rural markets.

\subsubsection{Learning from demand}

In experiments $C F_{7}-C F_{9}$ (Table 13), we quantify the impact of a better use of demand information to improve productivity. To implement them, we increase the coefficient of the term $\omega \times \mu$ in the productivity process by thirty percent: (i) for all stores $\left(C F_{7}\right)$; (ii) only for stores with demand shocks lower than average in the market $\left(C F_{8}\right)$; and (iii) only for stores with average

\footnotetext{
${ }^{47}$ In recent years, there is a well-documented increase in income inequality in many countries. The rise in income inequality implies that a shift from middle-income class, which includes the main part of consumers of traditional retailers, to high-income class that might prefer saving to consumption (Goolsbee, 2020).

${ }^{48}$ While we model aggregate income effects, our model is limited in fully understanding the heterogeneous impact of changes in income on consumer preferences, which is also not the main aim of our paper.

${ }^{49}$ We only quantify the changes in incumbents' behavior and not model entry and exit.
} 
sales per product category lower than the average in the market $\left(C F_{9}\right)$. In our setting, how much stores learn from demand information to produce innovations that increase productivity depends on their productivity level.

More intense learning for all stores in $C F_{7}$ enables stores to increase the number of product categories (larger in urban markets) and reduce labor and inventory demand. More product categories yield lower sales per product category in both markets (the drop is three times larger in rural than in urban markets). Intensified learning leads to heterogeneous responses in productivity improvements, where the median productivity increase in urban markets is approximately double that in rural markets (i.e., 3.4 vs. 1.7 percent). Stores in urban markets increase their sales as a consequence of their productivity advantage, unlike stores in rural markets. These findings point out that the combination of economies of scale and scope is particularly favorable for stores in urban markets. An increase in the learning from demand only for stores with low demand shocks in $C F_{8}$ yields similar results as in $C F_{7}$. However, the magnitude of the calculated changes is smaller because of lower productivity improvements.

In $C F_{9}$, we intensify learning only for stores with low sales per product category. The improvements in productivity are lower in $C F_{9}$ than in $C F_{7}$ and $C F_{8}$. In contrast to the previous two counterfactuals, $C F_{9}$ generates higher median sales per product category. The median sales per product increases approximately two times more in rural than in urban markets. In all three counterfactuals, there are no significant changes in market shares and HHI.

In summary, the findings from $C F_{7}-C F_{9}$ suggest that creating incentives for stores with low sales per product category to better use their demand information to produce "floor innovations" and increase their productivity is a successful strategy for retail development, especially in rural markets.

\section{Robustness}

This section discusses the robustness of the results using alternative modeling specifications.

Estimation of the service generating function. In this paper, the labor and the cost of products bought are used as proxy variables to recover productivity and demand shocks. However, instead of labor demand, the investment demand function can be used to recover productivity. The estimation results remain robust when using investment as a proxy, e.g., the 
estimated persistence in productivity and demand shocks is similar to our main results. Most importantly, productivity is still the main driver of a store's choices. We prefer the specification using labor demand because it uses all observations in the data and does not require positive investments.

The identification of the model uses the variables in $t-1$ as instruments (Ackerberg et al., 2007; Ackerberg et al., 2015). The estimates do not change when using local market variables in the current period $t$ as instruments. The persistence of productivity increases if the sales of other product categories in period $t\left(y_{-i j t}\right)$ are used as an instrument. As we expect, this finding indicates that the moment condition based on $y_{-i j t}$ does not hold and affects the identification of all parameters of the sales generating function. For this reason, using previous sales of other products $y_{-i j t-1}$ as an instrument is a better choice.

The relationship with input share estimators. Our model relates to methods that estimate input shares to analyze the relation between productivity and multiple products. In contrast, we use output shares and model economies to scope inside the sales technology and do not require data on prices. As in De Loecker et al. (2016), we have separability in inputs and outputs in the production technology and model firm/store productivity and not product-firm productivity. ${ }^{50}$ In the retail context, it is difficult to define a meaningful measure of productstore productivity. Using the aggregation over inputs and outputs, we can show that there is a direct relationship between the input shares from a Cobb-Douglas technology at the product level and output shares of transcendental technology. The relationship exists because both technologies use firm/store productivity, i.e., do not need to aggregate product productivity.

Separating input allocations per product can be difficult in service industries. For example, different machinery and equipment are used to carry or store different product categories at the same time to increase efficiency. The separation of all inputs is not fully consistent with economies of scale and scope. Since our focus is on economies of scope and not recovering product markups, transcendental technology that uses observed output shares is preferable because it does not require additional assumptions as are required to recover input shares (not observed in the data).

\footnotetext{
${ }^{50}$ See also Dhyne et al. (2016), Valmari (2016), Orr (2018).
} 


\section{Conclusions}

Retail businesses have changed drastically in recent years with substantial investments in new technologies, a sharp increase in warehouse clubs and a shift from products to services. This paper studies the determinants of economies of scope using a dynamic framework that models stores' incentives to hold variety based on their resources and received demand shocks in local markets. We use the implications of the equilibrium behavior from the store's dynamic model to recover the store's key primitives and evaluate their role in driving product variety (extensive margin), sales per product category (intensive margin), store-level sales and market shares. We estimate the model using novel data on a store's product categories, inputs and outputs in the retail sale of new goods in specialized stores in Sweden from 2003 to 2009.

Our model allows for economies of scale and scope and uses a multi-product sales technology and information on local market structure to estimate store productivity and demand shocks. In our setting, the store's sales per product category and total sales are endogenous and solutions to the system of multi-product sales equations for each store. Changes in product categories and demand shocks affect stores' market shares. In the counterfactual experiments, we use the estimated model and the systems of equations for sales and market share to compute the changes sales and local concentration measures.

The empirical findings highlight the trade-off between productivity and demand shocks for product variety in retail. Stores with high productivity and investment in new technology have a wider variety of products and sell more of all product categories. Stores with demand shocks have a smaller number of product categories and sell more of their top-selling product categories. Taken together, higher productivity and demand shocks both induce an increase in store-level sales and market shares. Improving economies of scope inside the store implies larger gains in store-level sales in rural than in urban markets,

Policy experiments show that subsidizing investments in new technologies increases the number of product categories and sales. Stores in urban markets benefit more from policies that promote technology investments because of their productivity advantage. We also find that stores learn from received demand shocks to increase future productivity. This process of learning from demand to increase product variety is crucial in rural markets. Reducing the role of uncertainty in productivity and demand shocks yields a net increase in the number of product 
categories and higher sales and market shares. Finally, a larger market size and higher income in the local market promote specialization where stores focus on fewer product categories.

Our model on the supply side can be integrated with a more general demand framework that allows for rich substitution patterns between products if data on product-level prices are available, which can provide richer implications for consumer surplus in addition to gains in variety. Although our suggested modeling framework is applied to detailed data on retailers, our analysis has broad implications for the many industries worldwide in which firms offer multiple products to evaluate the role of the determinants of economies of scope in improving firm performance due to policy changes. 


\section{References}

Ackerberg, D., L. Benkard, S. Berry, And A. Pakes (2007): Handbook of Econometrics,, Elsevier, vol. 6, chap. Econometric Tools for Analyzing Market Outcomes, 4171-4276.

Ackerberg, D., K. Caves, and G. Fraser (2015): "Identification Properties of Recent Production Function Estimators," Econometrica, 83, 2411-2451.

Ackerberg, D., X. Chen, And J. Hahn (2012): "A Practical Asymptotic Variance Estimator for Two-Step Semiparametric Estimators," Review of Economics and Statistics, 94, 481-498.

Adams, B. And K. R. Williams (2019): "Zone Pricing in Retail Oligopoly," American Economic Journal: Microeconomics, 11, 124-156.

Aminud, Y. And H. Mendelson (1989): "Inventory Behavior and Market Power: An Empirical Investigation," International Journal of Industrial Organization, 7, 269-280.

Anderson, S. And A. De Palma (2006): "Market performance with multi-product firms," Journal of Industrial Economics, 54, 95-124.

Anderson, S., A. De Palma, And J. F. Thisse (1987): "The CES is a discrete choice model?" Economics Letters, 24, 139-140.

Asker, J., A. Collard-Wexler, And J. De Loecker (2014): "Dynamic Inputs and Resource (Mis)Allocation," Journal of Political Economy, 122, 1013-1063.

Autor, D., D. Dorn, L. K. Katz, C. Patterson, and J. Van Reenen (2018): "The Fall of the Labor Share and the Rise of Superstar Frms," MIT mimeo.

Bailey, E. E. And A. F. Friedlaend (1982): "Market Structure and Multiproduct Industries," Journal of Economic Literature, 20, 1024-1048.

Bajari, P., L. Benkard, And J. Levin (2007): "Estimating Dynamic Models of Imperfect Competition," Econometrica, 75, 1331-1370.

BAsker, E. (2007): "The Causes and Consequences of Wal-Mart's Growth," Journal of Economic Perspectives, 21, 177-198.

(2015): "Change at the Checkout: Tracing the Impact of a Process Innovation," Journal of Industrial Economics, 63, 339-370.

Basker, E., S. Klimek, And P. Van (2012): "Supersize It: The Growth of Retail Chains and the Rise of the âBig-Boxâ Store," Journal of Economics and Management Strategy, 21, $541-582$.

Bernard, A. B., S. J. Redding, and P. K. Schott (2011): "Multiproduct Firms and Trade Liberalization," The Quarterly Journal of Economics, 126, 1271-1318. 
Berry, S., A. Eizenberg, And J. Waldfogel (2016): "Optimal product variety in radio markets," RAND Journal of Economics, 47, 463-497.

Berry, S., M. Gaynor, and F. Scott Morton (2019): "Do Increasing Markups Matter? Lessons from Empirical Industrial Organization," NBER Working Paper.

Berry, S. And J. Waldfogel (2001): "Do Mergers Increase Product Variety? Evidence from Radio Broadcasting," The Quarterly Journal of Economics, 116, 1009-1025.

BiLs, M. And J. A. Kahn (2000): "What Inventory Behavior Tells Us about Business Cycles," American Economic Review, 90, 458-481.

Braguinsky, S., A. Ohyama, T. Okazaki, and C. Syverson (2015): "Acquisitions, Productivity, and Profitability: Evidence from the Japanese Cotton Spinning Industry," American Economic Review, 105, 2086-2119.

Bronnenberg, B. And P. Ellickson (2015): "Adolescence and the Path to Maturity in Global Retail," Journal of Economic Perspectives, 29, 113.

Coen-Pirani, D. (2004): "Markups, Aggregation, and Inventory Adjustment," The American Economic Review, 94, 1328-1353.

Collard-Wexler, A. (2013): "Demand Fluctuations in the Ready-Mix Concrete Industry," Econometrica, 81, 1003-1037.

Collard-Wexler, A. And J. De Loecker (2015): "Reallocation and Technology: Evidence from the US Steel Industry," American Economic Review, 105, 131-171.

De Loecker, J. (2011): "Product Differentiation, Multi-Product Firms and Estimating the Impact of Trade Liberalization on Productivity," Econometrica, 79, 1407-1451.

De Loecker, J., P. Goldberg, A. Khandelwal, and N. Pavcnik (2016): "Prices, Markups, and Trade Reform," Econometrica, 84, 445-510.

Decker, R. A., J. C. Haltiwanger, R. S. Jarmin, And J. Miranda (2018): "Changing Business Dynamism and Productivity: Shocks vs. Responsiveness," NBER Working Paper.

Dhyne, E., A. Petrin, And V. Smeets (2016): "Multi-Product Firms, Import Competition, and the Evolution of Firm-product Technical Efficiencies," Working Paper, Univeristy of Minnesota.

Dhyne, E., A. Petrin, V. Smeets, And F. Warzynski (2017): "Multi-Product Firms, Import Competition, and the Evolution of Firm-Product Technical Efficiencies," Mimeo, University of Minnesota.

Doraszelski, U. And J. Jaumandreu (2013): "R\&D and Productivity: Estimating Endogenous Productivity," Review of Economic Studies, 80, 1338-1383. 
Draganska, M. And D. C. Jain (2005): "Product-Line Length As a Competitive Tool," Journal of Economics and Management Strategy, 14, 1-28.

Dube, J.-P. H., A. Hortacsu, And J. Joonhwi (2020): "Random-Coefficients Logit Demand Estimation with Zero-Valued Market Shares," Working Paper, Univeristy of Chicago.

EizenberG, A. (2014): "Upstream Innovation and Product Variety in the U.S. Home PC Market," Review of Economic Studies, 81, 1003-1045.

Ellickson, P. (2007): "Does Sutton apply to supermarkets?" The RAND Journal of Economics, 38, 43-59.

Ellickson, P., P. L. E. Grieco, And O. Khvastunov (2019): "Measuring Competition in Spatial Retail," Working paper.

FAn, Y. And C. YAng (2019): "Competition, Product Proliferation and Welfare: A Study of the US Smartphone Market," American Economic Journal: Microeconomics (Forthcoming).

Foster, L., J. Haltiwanger, and C. Syverson (2008): "Reallocation, Firm Turnover, and Efficiency: Selection on Productivity or Profitability?" American Economic Review, 98, $394-425$.

Fuss, M. And D. McFadden (1978): Production Economics: A Dual Approach to Theory and Applications (Vol I and II), North-Holland Publishing Company.

Gandhi, A., S. Navarro, and D. Rivers (2018): "On the Identification of Production Functions: How Heterogenous is Productivity?" Working paper.

Goolsbee, A. (2020): "Never Mind the Internet. Here's What's Killing Malls," The New York Times, article February 13, 2020.

Gorman, I. E. (1985): "Conditions for Economies of Scope in the Presence of Fixed Costs," RAND Journal of Economics, 16, 431-436.

Grieco, P. And R. McDevitT (2017): "Productivity and Quality in Health Care: Evidence from the Dialysis Industry," Review of Economic Studies, 84, 1071-1105.

Hicks, J. R. (1946): Value and Capital, Oxford, Clarendon Press, 2nd ed.

Holmes, T. J. (2001): "Bar Codes Lead to Frequent Deliveries and Superstores," The RAND Journal of Economics, 32, 708-725.

Hortacsu, A. And C. Syverson (2015): "The Ongoing Evolution of US Retail: A Format Tug-of-War," Journal of Economic Literature, 4, 89-112.

Hsieh, C. T. And E. Rossi-Hansberg (2019): "The Industrial Revolution in Services," NBER Working Paper. 
Humphreys, B., L. Maccini, And S. Schuh (2001): "Input and Output Inventories," Journal of Monetary Economics, 47, 347-375.

Iacoviello, M., F. Schiantarelli, and S. Schuh (2011): "Input and Output Inventories in General Equilibrium," International Economic Review, 52, 1179-1213.

Kumar, P. And H. Zhang (2018): "Productivity or Unexpected Demand Shocks: What Determines Firms' Investment and Exit Decisions?" Forthcoming, International Economic Review.

Levinsohn, J. And A. Petrin (2003): "Estimating Production Functions Using Inputs to Control for Unobservables," Review of Economic Studies, 70, 317-341.

Maican, F. And M. Orth (2015): "A Dynamic Analysis of Entry Regulations and Productivity in Retail Trade," International Journal of Industrial Organization, 40, 67-80.

- (2017): "Productivity Dynamics and the role of "Big-Box" Entrants in Retailing," Journal of Industrial Economics, LXV, 397-438.

(2018a): "Entry Regulations, Welfare and Determinants of Market Structure," International Economic Review, 59, 727-756.

— (2018b): "Inventory Behavior, Demand, and Productivity in Retail," CEPR Working Paper.

(2019): "Entry Regulations and Product Variety in Retail," Mimeo, KU Leuven.

Maican, F., M. Orth, M. J. Roberts, And V. A. Vuong (2018): "R\&D Dynamics and Its Impact on Productivity and Export Demand in Swedish Manufacturing," Mimeo, KU Leuven.

Matzkin, R. L. (2008): "Identification in Nonparametric Simultaneous Equations Models," Econometrica, 76, 945-978.

Mundlak, Y. (1964): "Transcendental Multiproduct Production Functions," International Economic Review, 5, 273-284.

Nordregio (2011): "Perspectives on rural development in the Nordic countries â Policies, governance, development initiatives," Nordic Centre for Spatial Development Working Paper.

OI, W. (1992): Output Measurement in the Service Sectors, NBER, chap. Productivity in the Distributive Trades: The Shopper and the Economies of Massed Reserves, 161-193.

Olley, S. And A. Pakes (1996): "The Dynamics of Productivity in the Telecommunications Equipment Industry," Econometrica, Vol. 64, 1263-1297.

OrR, S. (2018): "Productivity Dispersion, Import Competition, and Specialization in Multiproduct Plants," Mimeo, University of Toronto. 
Pakes, A. (1994): chap. The Estimation of Dynamic Structural Models: Problems and Prospects Part II. Mixed Continuous-Discrete Control Models and Market Interactions, Laffont, J. J. and Sims, C. eds, Advances in Econometrics: Proceedings of the 6th World Congress of the Econometric Society, Chapter 5.

Panzar, J. C. And R. D. Willig (1981): "Economies of Scope," The American Economic Review, 71, 268-272.

Quan, T. W. AND K. R. Williams (2018): "Product variety, across-market demand heterogeneity, and the value of online retail," RAND Journal of Economics, 49, 877-913.

RYAn, S. (2012): "The Costs of Environmental Regulation in a Concentrated Industry," Econometrica, 80, 1019-1062.

SCB (2015): "Retail trade areas 2015," Tech. rep., Statistics Sweden.

SweEting, A. (2010): "The effects of mergers on product positioning: evidence from the music radio industry," The RAND Journal of Economics, 41.

- (2013): "Dynamic Product Positioning in Differentiated Product Markets: The Effect of Fees for Musical Performance Rights on the Commercial Radio Industry," Econometrica, 81, 1763-1803.

Syverson, C. (2011): "What Determines Productivity?" Journal of Economic Literature, 49, $326-365$.

Valmari, N. (2016): "Estimating Production Functions of Multiproduct Firms," ETLA WorkingPapers.

Verboven, F. (1996): "The Nested Logit Model and Representative Consumer Theory," Economics Letters, 50, 57-63.

Wen, Y. (2011): "Input and Output Inventory Dynamics," American Economic Journal: Macroeconomics, 3, 181-212.

Wooldridge, J. M. (2009): "On Estimating Firm-Level Production Functions Using Proxy Variables to Control for Unobservables," Economics Letters, 104, 112-114. 
Table 1: Descriptive statistics

\begin{tabular}{|c|c|c|c|c|c|c|c|c|c|c|}
\hline \multirow[t]{2}{*}{ Year } & \multicolumn{2}{|c|}{ Sales } & \multicolumn{2}{|c|}{$\begin{array}{c}\text { No. of } \\
\text { employees }\end{array}$} & \multicolumn{2}{|c|}{$\begin{array}{c}\text { Capital } \\
\text { stock }\end{array}$} & \multicolumn{2}{|c|}{$\begin{array}{c}\text { Cost of } \\
\text { goods }\end{array}$} & \multicolumn{2}{|c|}{$\begin{array}{l}\text { Inventory } \\
\text { end year }\end{array}$} \\
\hline & $Q_{50}$ & IQR & $Q_{50}$ & IQR & $Q_{50}$ & IQR & $Q_{50}$ & IQR & $Q_{50}$ & IQR \\
\hline 2004 & 11.620 & 27.767 & 7 & 10 & 0.394 & 0.970 & 7.282 & 18.892 & 1.823 & 5.154 \\
\hline 2005 & 11.207 & 20.463 & 7 & 7 & 0.392 & 0.979 & 6.865 & 13.378 & 2.060 & 4.050 \\
\hline 2006 & 14.214 & 25.135 & 7 & 9 & 0.475 & 1.101 & 8.783 & 17.943 & 2.378 & 4.987 \\
\hline 2007 & 11.193 & 23.452 & 7 & 9 & 0.435 & 1.129 & 6.572 & 15.191 & 1.990 & 5.040 \\
\hline 2008 & 11.328 & 24.713 & 7 & 10 & 0.468 & 1.217 & 6.805 & 16.382 & 2.042 & 5.816 \\
\hline 2009 & 11.417 & 24.818 & 7 & 10 & 0.522 & 1.283 & 6.785 & 15.840 & 2.162 & 5.572 \\
\hline \multirow[t]{2}{*}{$\overline{\text { Year }}$} & \multicolumn{2}{|c|}{$\begin{array}{c}\text { No. of } \\
\text { products }\end{array}$} & \multicolumn{2}{|c|}{$\begin{array}{c}\text { HHI } \\
\text { product }\end{array}$} & \multicolumn{2}{|c|}{$\begin{array}{c}\text { Market } \\
\text { share }\end{array}$} & \multicolumn{2}{|c|}{$\begin{array}{c}\text { HHI } \\
\text { market }\end{array}$} & \multicolumn{2}{|c|}{$\begin{array}{c}\mathrm{C} 4 \\
\text { market }\end{array}$} \\
\hline & $Q_{50}$ & IQR & $Q_{50}$ & IQR & $Q_{50}$ & IQR & $Q_{50}$ & IQR & $Q_{50}$ & IQR \\
\hline 2004 & 3 & 2 & 0.738 & 0.380 & 0.349 & 0.694 & 0.363 & 0.493 & 0.919 & 0.306 \\
\hline 2005 & 4 & 2 & 0.495 & 0.333 & 0.339 & 0.635 & 0.364 & 0.437 & 0.918 & 0.286 \\
\hline 2006 & 4 & 2 & 0.549 & 0.332 & 0.375 & 0.658 & 0.381 & 0.467 & 0.929 & 0.291 \\
\hline 2007 & 4 & 3 & 0.601 & 0.364 & 0.372 & 0.626 & 0.361 & 0.427 & 0.925 & 0.272 \\
\hline 2008 & 3 & 3 & 0.707 & 0.468 & 0.341 & 0.657 & 0.361 & 0.466 & 0.930 & 0.267 \\
\hline 2009 & 3 & 3 & 0.655 & 0.448 & 0.378 & 0.665 & 0.393 & 0.448 & 0.941 & 0.238 \\
\hline \multicolumn{11}{|c|}{$\begin{array}{l}\text { NOTE: Sales (excl. VAT), capital stock, inventories, cost of goods, and wages are measured in millions } \\
\text { of } 2000 \mathrm{SEK}(1 \mathrm{USD}=7.3 \mathrm{SEK}, 1 \mathrm{EUR}=9.3 \mathrm{SEK}) . Q_{50} \text { and IQR are interquartile ranges. Capital stock } \\
\text { includes only machinery and equipment and is computed using the perpetual inventory method. The } \\
\text { HHI product is the Herfindahl-Hirschman index for the product categories at the store level computed } \\
\text { using sales. The HHI and C4 are the Herfindahl-Hirschman index and the four-store concentration ratio }\end{array}$} \\
\hline
\end{tabular}

Table 2: The correlations in the data and their evolution

\begin{tabular}{|c|c|c|c|c|c|c|c|}
\hline \multirow[t]{2}{*}{ Correlation $(\mathrm{x}, \mathrm{y})$} & \multicolumn{7}{|c|}{ Year } \\
\hline & 2003 & 2004 & 2005 & 2006 & 2007 & 2008 & 2009 \\
\hline \multicolumn{8}{|l|}{ Extensive margin } \\
\hline (Number of products, Capital stock per employee) & 0.047 & 0.040 & 0.003 & -0.019 & 0.074 & 0.067 & 0.121 \\
\hline (Number of products, Sales per cost of goods) & -0.030 & -0.027 & -0.003 & -0.011 & -0.017 & -0.012 & -0.015 \\
\hline (Number of products, Market share) & 0.137 & 0.075 & 0.071 & 0.060 & 0.071 & 0.071 & 0.048 \\
\hline \multicolumn{8}{|l|}{ Intensive margins } \\
\hline (Sales per product, Capital per employee) & 0.204 & 0.250 & 0.111 & 0.029 & 0.090 & 0.136 & 0.119 \\
\hline (Sales per product, Wages per employee) & 0.320 & 0.236 & 0.207 & 0.225 & 0.192 & 0.228 & 0.252 \\
\hline (Entropy of product sales, Inventory per product) & 0.022 & 0.098 & 0.089 & 0.068 & 0.053 & 0.022 & 0.021 \\
\hline (Entropy of product sales, Sales per employee) & 0.046 & 0.075 & 0.063 & 0.070 & 0.057 & 0.012 & -0.061 \\
\hline \multicolumn{8}{|l|}{ Local market power } \\
\hline (Market share, Entropy of product sales) & -0.071 & -0.042 & -0.076 & -0.090 & -0.065 & -0.067 & -0.038 \\
\hline (Market share, Inventory end of year) & 0.255 & 0.182 & 0.142 & 0.145 & 0.086 & 0.187 & 0.185 \\
\hline (Market share, Sales per employee) & 0.194 & 0.059 & 0.071 & 0.123 & 0.084 & 0.093 & 0.111 \\
\hline (Market share, Capital stock per employee) & 0.052 & 0.102 & 0.011 & -0.025 & -0.010 & 0.025 & 0.019 \\
\hline
\end{tabular}

NOTE: Entropy measures store diversification in sales and is computed for each store $j$ based on market share of each product category $i$ inside store, i.e., $E_{j t}=\sum_{i} m s_{i j t} \ln \left(m s_{i j t}\right)$ (Bernard et al., 2011). A large measure of entropy suggests that the store focuses on top sales categories. 
Table 3: Reduced-form: The effect of local competition, store's market share and margins on the number of product categories

\begin{tabular}{|c|c|c|c|c|c|c|c|c|}
\hline & \multicolumn{4}{|c|}{ Number of product categories } & \multicolumn{4}{|c|}{ HHI product category } \\
\hline & Est. & Std. & Est. & Std. & Est. & Std. & Est. & Std. \\
\hline \multicolumn{9}{|c|}{ Panel A: The effect of local competition } \\
\hline HHI & -0.1400 & 0.4589 & & & -0.0047 & 0.0253 & & \\
\hline $\mathrm{C} 4$ & & & -0.6704 & 0.7670 & & & 0.0941 & 0.0494 \\
\hline Log of capital stock & -0.0102 & 0.0689 & -0.0102 & 0.0680 & 0.0125 & 0.0053 & 0.0125 & 0.0051 \\
\hline Store fixed-effect & \multicolumn{2}{|c|}{ Yes } & \multicolumn{2}{|c|}{ Yes } & \multicolumn{2}{|c|}{ Yes } & \multicolumn{2}{|c|}{ Yes } \\
\hline Year fixed-effect & \multicolumn{2}{|c|}{ Yes } & \multicolumn{2}{|c|}{ Yes } & \multicolumn{2}{|c|}{ Yes } & \multicolumn{2}{|c|}{ Yes } \\
\hline$R^{2}$-adjusted & \multicolumn{2}{|c|}{0.0052} & \multicolumn{2}{|c|}{0.0057} & \multicolumn{2}{|c|}{0.0096} & \multicolumn{2}{|c|}{0.0104} \\
\hline \multicolumn{9}{|c|}{ Panel B: The effect of store's market share and margins } \\
\hline Log of store's market share & 0.1087 & 0.1021 & & & 0.0141 & 0.0093 & & \\
\hline Log of store's margin & & & -0.2755 & 0.1055 & & & 0.0451 & 0.0181 \\
\hline Log of capital stock & -0.0164 & 0.0645 & -0.0223 & 0.0709 & 0.0118 & 0.0053 & 0.0136 & 0.0089 \\
\hline Store fixed-effect & \multicolumn{2}{|c|}{ Yes } & \multicolumn{2}{|c|}{ Yes } & \multicolumn{2}{|c|}{ Yes } & \multicolumn{2}{|c|}{ Yes } \\
\hline Year fixed-effect & \multicolumn{2}{|c|}{ Yes } & \multicolumn{2}{|c|}{ Yes } & \multicolumn{2}{|c|}{ Yes } & \multicolumn{2}{|c|}{ Yes } \\
\hline$R^{2}$-adjusted & \multicolumn{2}{|c|}{0.0056} & \multicolumn{2}{|c|}{0.0065} & \multicolumn{2}{|c|}{0.0102} & \multicolumn{2}{|c|}{0.0114} \\
\hline \multicolumn{9}{|c|}{$\begin{array}{l}\text { NOTE: HHI and C4 are the Herfindahl-Hirschman index and the four-store concentration ratio in a local } \\
\text { market for a five-digit industry and are computed using sales. A store's margins are proxied using the ratio } \\
\text { (net sales - cost of goods)/net sales. The first difference estimator is used. Standard errors are clustered at } \\
\text { the five-digit industry. }\end{array}$} \\
\hline
\end{tabular}

Table 4: The relationship between productivity and market share at the store level

\begin{tabular}{|c|c|c|c|c|}
\hline & \multicolumn{4}{|c|}{ Log of labor productivity in period $t$} \\
\hline & \multicolumn{2}{|c|}{ Static } & \multicolumn{2}{|c|}{ Dynamic } \\
\hline & Est. & Std. & Est. & Std. \\
\hline Market share period $t$ & 0.4048 & 0.1009 & & \\
\hline Log of labor productivity in period $t-1$ & & & 0.8577 & 0.0289 \\
\hline Market share in period $t-1$ & & & 0.0453 & 0.0259 \\
\hline Store fixed-effects & \multicolumn{2}{|c|}{ Yes } & \multicolumn{2}{|c|}{ No } \\
\hline Year fixed-effects & \multicolumn{2}{|c|}{ Yes } & \multicolumn{2}{|c|}{ Yes } \\
\hline$R^{2}$-adjusted & \multicolumn{2}{|c|}{0.0254} & \multicolumn{2}{|c|}{0.8167} \\
\hline
\end{tabular}

NOTE: Standard errors are clustered at the five-digit industry. 
Table 5: Estimation of the multi-product sales generating function

\begin{tabular}{|c|c|c|c|c|}
\hline & \multicolumn{2}{|c|}{ OLS } & \multicolumn{2}{|c|}{ Two-step estimation } \\
\hline & Estimate & Std. & Estimate & Std. \\
\hline Log no. of employees & 0.7866 & 0.0290 & 0.5582 & 0.0423 \\
\hline Log of capital & 0.0599 & 0.0129 & 0.2833 & 0.0276 \\
\hline Log of inventory & 1.0367 & 0.0212 & 0.4937 & 0.0237 \\
\hline Log of sales of other products & -0.8959 & 0.0098 & -0.8562 & 0.0115 \\
\hline Log of sales outside option & -0.0055 & 0.0065 & 0.2240 & 0.014 \\
\hline Log of population & 0.0233 & 0.0218 & 0.1396 & 0.036 \\
\hline Log of population density & 0.0076 & 0.0151 & 0.1903 & 0.049 \\
\hline Log of income & 34.7509 & 13.2213 & 0.9340 & 0.057 \\
\hline Log of income squared & -3.2989 & 1.2435 & -0.0915 & 0.017 \\
\hline Coef. of no. of products $\left(\rho_{n p}\right)$ & & & 0.2137 & 0.0364 \\
\hline Elasticity of substitution & & & \multicolumn{2}{|c|}{4.630} \\
\hline Year fixed-effect & \multicolumn{2}{|c|}{ Yes } & \multicolumn{2}{|c|}{ Yes } \\
\hline No. of obs. & \multicolumn{2}{|c|}{16,759} & \multicolumn{2}{|c|}{16,759} \\
\hline
\end{tabular}

NOTE: The dependent variable is the log of sales of a product category at the store level. Labor is measured as the number of full-time adjusted employees. Sales of other product categories are measured at the store level. Sales of the outside option measures total sales of the other products of all other five-digit SNI codes at the local market. All regressions include year dummies and five-digit SNI dummies. $O L S$ refers to an ordinary least squares regression. Two-step estimation refers to the extended Olley and Pakes (1996) estimation method presented in Section 2 (Maican and Orth, 2019). Reported standard errors (in parentheses) are computed using Ackerberg et al. (2012).

Table 6: Estimation of structural parameters: Productivity and demand shock processes

\begin{tabular}{|c|c|c|c|c|c|}
\hline \multicolumn{3}{|c|}{ Productivity $\left(\omega_{t}\right)$ process } & \multicolumn{3}{|c|}{ Demand shocks $\left(\mu_{t}\right)$ process } \\
\hline & Estimate & Std. & & Estimate & Std. \\
\hline Productivity $\left(\omega_{t-1}\right)$ & 0.8540 & 0.0649 & Demand shocks $\left(\mu_{t-1}\right)$ & 0.8596 & 0.0224 \\
\hline Productivity squared $\left(\omega_{t-1}^{2}\right)$ & -0.0375 & 0.0181 & Demand shocks squared $\left(\mu_{t-1}^{2}\right)$ & -0.0195 & 0.0022 \\
\hline Productivity cubic $\left(\omega_{t-1}^{3}\right)$ & -0.0043 & 0.0015 & Demand shocks cubic $\left(\mu_{t-1}^{3}\right)$ & -0.0005 & 0.0002 \\
\hline Prod.*Dem. shocks $\left(\omega_{t-1} \times \mu_{t-1}\right)$ & 0.0946 & 0.0123 & & & \\
\hline Demand shocks $\left(\mu_{t-1}\right)$ & 0.0172 & 0.0025 & & & \\
\hline Year fixed-effects & \multicolumn{2}{|c|}{ Yes } & Year fixed-effects & \multicolumn{2}{|c|}{ Yes } \\
\hline Sub-sector fixed-effects & \multicolumn{2}{|c|}{ Yes } & Sub-sector fixed-effects & \multicolumn{2}{|c|}{ Yes } \\
\hline Adjusted R-squared & \multicolumn{2}{|c|}{0.981} & Adjusted R-squared & \multicolumn{2}{|c|}{0.792} \\
\hline \multirow[t]{2}{*}{ Coefficients of $\omega_{t-1}$ terms are zero } & F-test & p-value & & & \\
\hline & 424.139 & 0.000 & & & \\
\hline \multirow[t]{2}{*}{ Coefficients of $\mu_{t-1}$ terms are zero } & F-test & p-value & & & \\
\hline & 27.713 & 0.000 & & & \\
\hline Persistence $\left(d \omega_{t} / d \omega_{t-1}\right)$ & \multirow{2}{*}{\multicolumn{2}{|c|}{$\begin{array}{l}0.856 \\
0.013\end{array}$}} & Persistence $\left(d \mu_{t} / d \mu_{t-1}\right)$ & \multirow{2}{*}{\multicolumn{2}{|c|}{0.929}} \\
\hline Effect of demand shocks $\left(d \omega_{t} / d \mu_{t-1}\right)$ & & & & & \\
\hline
\end{tabular}

NOTE: Productivity is estimated using the two-step estimation method in Section 2. Mean values are presented for the marginal effects. 
Table 7: The impact of store and market characteristics on product category

\begin{tabular}{|c|c|c|c|c|c|c|}
\hline \multirow[t]{2}{*}{ Dependent variable } & \multicolumn{2}{|c|}{$\begin{array}{l}\text { No. product } \\
\text { categories } \\
\left(n p_{j t}\right)\end{array}$} & \multicolumn{2}{|c|}{$\begin{array}{l}\text { HHI product } \\
\text { categories } \\
\text { in a store }\end{array}$} & \multicolumn{2}{|c|}{$\begin{array}{c}\text { Entropy of } \\
\text { sales of product } \\
\text { categories }\end{array}$} \\
\hline & Est. & Std. & Est. & Std. & Est. & Std. \\
\hline Productivity $\left(\omega_{t}\right)$ & 1.2058 & 0.1876 & -0.0738 & 0.0094 & -0.1568 & 0.0234 \\
\hline Demand shocks $\left(\mu_{t}\right)$ & -0.1647 & 0.0377 & 0.0116 & 0.0018 & 0.0228 & 0.0044 \\
\hline Log of capital $\left(k_{t}\right)$ & 0.3469 & 0.0978 & -0.0162 & 0.0070 & -0.0348 & 0.0130 \\
\hline $\log$ of inventories $\left(n_{t}\right)$ & -0.1218 & 0.0306 & 0.0060 & 0.0173 & 0.0231 & 0.0268 \\
\hline Log of population $\left(p o p_{t}\right)$ & -1.2601 & 0.2976 & 0.0309 & 0.0390 & 0.0746 & 0.0627 \\
\hline Log of population density (popdenst) & 0.4861 & 0.3686 & -0.0101 & 0.0690 & -0.0235 & 0.1090 \\
\hline Log of income $\left(i n c_{t}\right)$ & -2.6027 & 3.2836 & -0.4403 & 0.1413 & -0.7676 & 0.3607 \\
\hline Store fixed-effects & \multicolumn{2}{|c|}{ Yes } & \multicolumn{2}{|c|}{ Yes } & \multicolumn{2}{|c|}{ Yes } \\
\hline Year fixed-effects & \multicolumn{2}{|c|}{ Yes } & \multicolumn{2}{|c|}{ Yes } & \multicolumn{2}{|c|}{ Yes } \\
\hline Adjusted R-squared & \multicolumn{2}{|c|}{0.119} & \multicolumn{2}{|c|}{0.053} & \multicolumn{2}{|c|}{0.061} \\
\hline
\end{tabular}

Table 8: Determinants of inventory performance and store's market share

\begin{tabular}{|c|c|c|c|c|c|c|}
\hline \multirow[t]{2}{*}{ Dependent variable } & \multicolumn{2}{|c|}{$\begin{array}{c}\text { Inventory per product } \\
\text { before sales } \\
\left(\ln \left(A_{j t} / n p_{j t}\right)\right)\end{array}$} & \multicolumn{2}{|c|}{$\begin{array}{c}\text { Inventory per product } \\
\text { after sales } \\
\ln \left(N_{j t+1} / n p_{j t}\right)\end{array}$} & \multicolumn{2}{|c|}{$\begin{array}{l}\text { Store's market } \\
\text { share }\end{array}$} \\
\hline & Est. & Std. & Est. & Std. & Est. & Std. \\
\hline Productivity $\left(\omega_{t}\right)$ & 0.0483 & 0.0239 & -0.1208 & 0.0255 & 0.1654 & 0.0120 \\
\hline Demand shocks $\left(\mu_{t}\right)$ & 0.0599 & 0.0049 & 0.0550 & 0.0053 & 0.0132 & 0.0025 \\
\hline Log of capital $\left(k_{t}\right)$ & 0.0823 & 0.0177 & -0.0119 & 0.0189 & 0.0945 & 0.0089 \\
\hline Log of inventories $\left(n_{t}\right)$ & 0.0212 & 0.0177 & 0.0229 & 0.0189 & 0.0517 & 0.0089 \\
\hline Log of population $\left(\right.$ pop $\left._{t}\right)$ & 0.6717 & 0.0876 & 0.5717 & 0.0934 & -0.6770 & 0.0442 \\
\hline Log of population density (popdenst) & -0.4953 & 0.0963 & -0.3958 & 0.1026 & -0.0884 & 0.0486 \\
\hline Log of income $\left(i n c_{t}\right)$ & 0.0878 & 0.9702 & 1.1587 & 1.0338 & 1.9653 & 0.4901 \\
\hline Store fixed-effects & \multicolumn{2}{|c|}{ Yes } & \multicolumn{2}{|c|}{ Yes } & \multicolumn{2}{|c|}{ Yes } \\
\hline Year fixed-effects & \multirow{2}{*}{\multicolumn{2}{|c|}{ Yes }} & \multirow{2}{*}{\multicolumn{2}{|c|}{$\begin{array}{c}\text { Yes } \\
0.051\end{array}$}} & \multirow{2}{*}{\multicolumn{2}{|c|}{$\begin{array}{c}\text { Yes } \\
0.257\end{array}$}} \\
\hline Adjusted R-squared & & & & & & \\
\hline
\end{tabular}

NOTE: Productivity and demand shocks are estimated using the two-step estimation method in Section

2. Store regressions control for the average wage. 
Table 9: Estimation of the investment, labor, and inventory demand functions

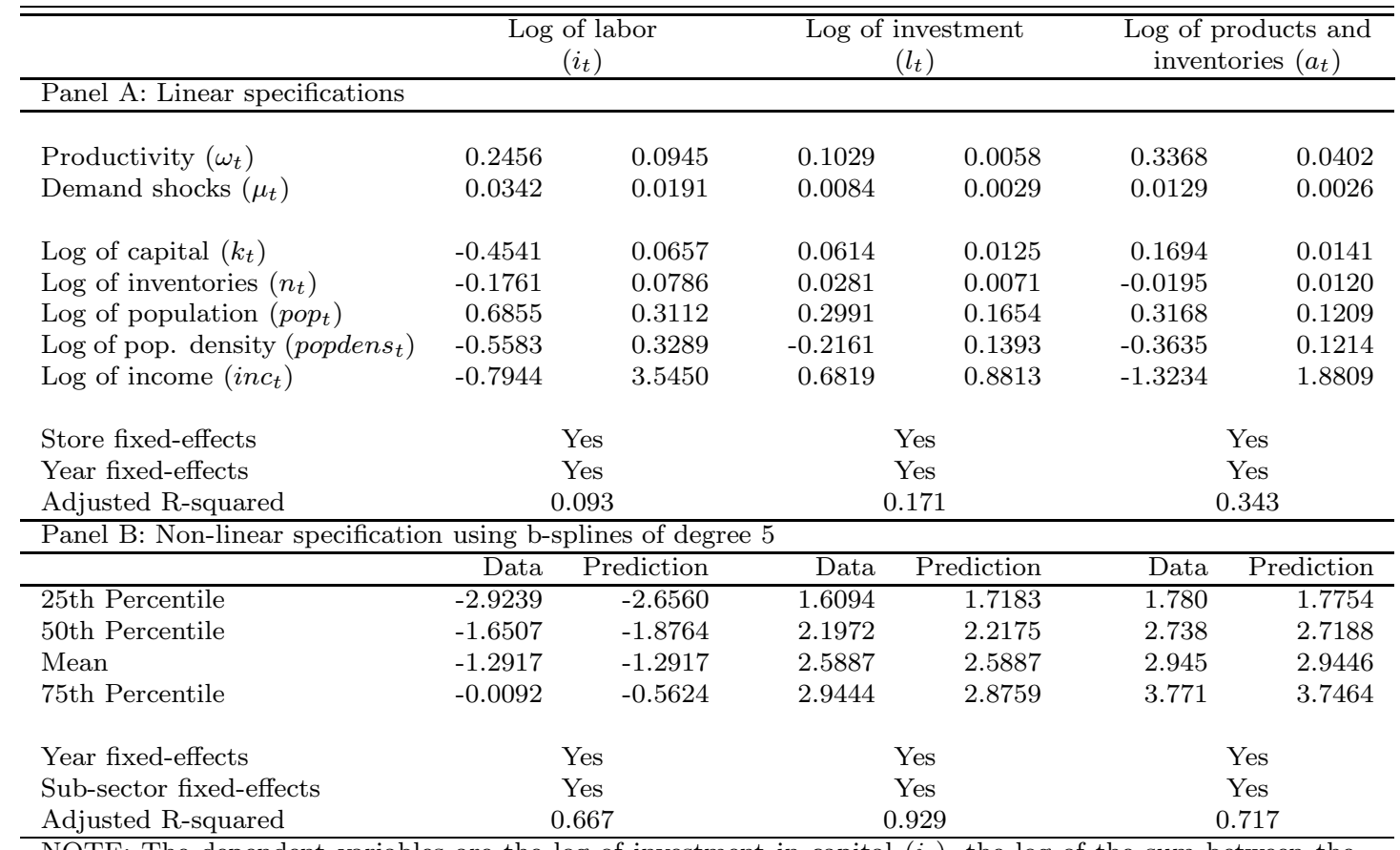

NOTE: The dependent variables are the log of investment in capital $\left(i_{t}\right)$, the log of the sum between the inventories at the beginning of the year $\left(n_{t}\right)$ and the cost of products bought during the year $\left(a_{t}\right)$, and the log of inventories at the end of the year $\left(n_{t+1}\right)$. All regressions include an intercept and control for the average wage. Productivity and demand shocks are estimated using the two-step estimation method in Section 2.

Table 10: Counterfactual experiments: The role of economics of scope and investments in technology in rural and urban markets

\begin{tabular}{|c|c|c|c|c|}
\hline & \multicolumn{2}{|c|}{ Rural markets } & \multicolumn{2}{|c|}{ Urban markets } \\
\hline & Median & Std. & Median & Std. \\
\hline \multicolumn{5}{|c|}{$C F_{1}$ : Improve in the economies of scope keeping variety constant } \\
\hline \multicolumn{5}{|c|}{ Change in store's number of products } \\
\hline Change in store's sales per product & 14.32 & 14.29 & 12.58 & 14.04 \\
\hline Change in store's total sales & 14.32 & 14.29 & 12.58 & 14.04 \\
\hline Change in market's total sales & 15.27 & 17.42 & 15.04 & 21.49 \\
\hline \multicolumn{5}{|l|}{$C F_{2}:$ Subsidize investments in technology } \\
\hline Change in store's number of products & 1.95 & 0.001 & 1.94 & 0.04 \\
\hline Change in store's sales per product & 1.37 & 1.43 & 2.08 & 1.49 \\
\hline Change in store's total sales & 3.61 & 0.86 & 4.23 & 0.88 \\
\hline Change in store's market share & 0.17 & 0.09 & 0.13 & 0.11 \\
\hline Change in market HHI & 0.13 & 0.07 & 0.06 & 0.20 \\
\hline Change in store's labor demand & -0.17 & 2.20 & -0.71 & 1.85 \\
\hline Change in store's inventory demand & -0.34 & 0.99 & -1.01 & 1.39 \\
\hline
\end{tabular}

NOTE: All numbers are in percentages. There are no changes in stores' productivity, demand shocks, and capital stock. In $C F_{1}$, we decrease the scope coefficient $\alpha_{y}$ by 15 percent. In $\mathrm{CF}_{2}$, we subsidize the investments in technology for all stores, i.e., capital stock increases by 30 percent. 
Table 11: Counterfactual experiments: Trade-offs under uncertainty - Benefits of maintaining productivity and received demand shocks over time

\begin{tabular}{|c|c|c|c|c|}
\hline & \multicolumn{2}{|c|}{ Rural markets } & \multicolumn{2}{|c|}{ Urban markets } \\
\hline & Median & Std. & Median & Std. \\
\hline \multicolumn{5}{|c|}{$C F_{3}:$ Higher demand shocks persistence over time } \\
\hline Change in store's number of products & -0.85 & 1.39 & -1.49 & 1.40 \\
\hline Change in store's sales per product & 2.93 & 1.32 & 3.60 & 1.97 \\
\hline Change in store's total sales & 2.17 & 1.63 & 2.17 & 0.83 \\
\hline Change in store's market share & 0.59 & 0.76 & 0.88 & 1.01 \\
\hline Change in market HHI & 1.00 & 0.62 & 0.05 & 2.13 \\
\hline Change in store's demand shocks & 5.97 & 6.60 & 12.84 & 12.18 \\
\hline Change in store's labor demand & 2.70 & 1.41 & 1.68 & 1.74 \\
\hline Change in store's inventory demand & 3.76 & 1.88 & 1.90 & 2.72 \\
\hline \multicolumn{5}{|c|}{$\bar{C} C F_{4}:$ Improve both productivity and demand shocks persistence over time } \\
\hline Change in store's number of products & 5.22 & 1.14 & 4.09 & 1.63 \\
\hline Change in store's sales per product & 10.00 & 3.03 & 9.57 & 2.83 \\
\hline Change in store's total sales & 14.24 & 2.67 & 13.93 & 2.72 \\
\hline Change in store's market share & 1.06 & 1.05 & 1.23 & 1.25 \\
\hline Change in market HHI & 1.04 & 0.78 & 0.20 & 2.54 \\
\hline Change in store's demand shocks & 7.30 & 6.60 & 12.84 & 12.18 \\
\hline Change in store's productivity & 26.54 & 5.47 & 25.86 & 4.94 \\
\hline Change in store's labor demand & 0.48 & 1.64 & 0.01 & 1.84 \\
\hline Change in store's inventory demand & 3.43 & 2.13 & 1.41 & 2.91 \\
\hline
\end{tabular}

Table 12: Counterfactual experiments: The role of demand in rural and urban markets

\begin{tabular}{|c|c|c|c|c|}
\hline & \multicolumn{2}{|c|}{ Rural markets } & \multicolumn{2}{|c|}{ Urban markets } \\
\hline & Median & Std. & Median & Std. \\
\hline \multicolumn{5}{|l|}{$C F_{5}:$ Increase in average income } \\
\hline Change in store's number of products & -2.49 & 0.001 & -2.48 & 0.06 \\
\hline Change in store's sales per product & 1.20 & 1.43 & 1.78 & 1.60 \\
\hline Change in store's total sales & -2.08 & 0.99 & -1.06 & 0.73 \\
\hline Change in store's market share & 0.43 & 0.30 & 0.52 & 0.35 \\
\hline Change in market HHI & 0.47 & 0.18 & 0.28 & 0.61 \\
\hline Change in store's labor demand & -3.47 & 2.18 & -1.26 & 1.86 \\
\hline Change in store's inventory demand & 1.27 & 1.26 & 0.76 & 1.01 \\
\hline \multicolumn{5}{|l|}{$C F_{6}:$ Increase in market size (population) } \\
\hline Change in store's number of products & -3.49 & 0.001 & -3.48 & 0.09 \\
\hline Change in store's sales per product & 5.19 & 2.56 & 3.93 & 1.23 \\
\hline Change in store's total sales & 1.19 & 1.87 & -0.10 & 0.96 \\
\hline Change in store's market share & -0.30 & 0.16 & -0.24 & 0.20 \\
\hline Change in market HHI & -0.58 & 0.38 & -0.11 & 0.36 \\
\hline Change in store's labor demand & 3.58 & 1.85 & 0.31 & 1.28 \\
\hline Change in store's inventory demand & 0.57 & 4.44 & 0.07 & 1.07 \\
\hline
\end{tabular}


Table 13: Counterfactual experiments: The role of learning from demand to improve productivity in rural and urban markets

\begin{tabular}{|c|c|c|c|c|}
\hline & \multicolumn{2}{|c|}{ Rural markets } & \multicolumn{2}{|c|}{ Urban markets } \\
\hline & Median & Std. & Median & Std. \\
\hline \multicolumn{5}{|c|}{$C F_{7}$ : Improve productivity by a better use of information from consumers } \\
\hline Change in store's number of products & 0.38 & 0.001 & 0.72 & 0.73 \\
\hline Change in store's sales per product & -1.26 & 1.32 & -0.36 & 1.60 \\
\hline Change in store's total sales & -1.04 & 1.63 & 0.48 & 2.22 \\
\hline Change in store's market share & 0.04 & 0.05 & 0.04 & 0.06 \\
\hline Change in market HHI & 0.02 & 0.04 & 0.00 & 0.01 \\
\hline Change in store's productivity & 1.78 & 2.05 & 3.35 & 3.58 \\
\hline Change in store's labor demand & -4.74 & 1.51 & -3.22 & 3.35 \\
\hline Change in store's inventory demand & -2.27 & 3.08 & -0.77 & 4.71 \\
\hline \multicolumn{5}{|c|}{$\begin{array}{l}C F_{8}: \text { Improve productivity by a better use of information from consumers } \\
\text { for stores with lower lower demand shocks than average }\end{array}$} \\
\hline Change in store's number of products & 0.32 & 0.001 & 0.63 & 0.67 \\
\hline Change in store's sales per product & -1.34 & 1.17 & -0.58 & 1.70 \\
\hline Change in store's total sales & -1.04 & 1.46 & 0.14 & 2.08 \\
\hline Change in store's market share & 0.03 & 0.05 & 0.04 & 0.06 \\
\hline Change in market HHI & 0.02 & 0.04 & -0.01 & 0.12 \\
\hline Change in store's productivity & 1.43 & 1.67 & 2.64 & 3.09 \\
\hline Change in store's labor demand & -4.55 & 1.38 & -3.17 & 2.95 \\
\hline Change in store's inventory demand & -2.01 & 2.87 & -0.91 & 4.07 \\
\hline \multicolumn{5}{|c|}{$\begin{array}{l}C F_{9}: \text { Improve productivity by a better use of information from consumers } \\
\text { for stores with lower sales per product than average }\end{array}$} \\
\hline Change in store's number of products & 0.03 & 0.17 & 0.19 & 0.51 \\
\hline Change in store's sales per product & 0.79 & 2.05 & 0.36 & 1.3 \\
\hline Change in store's total sales & 0.79 & 2.05 & 0.54 & 1.71 \\
\hline Change in store's market share & 0.00 & 0.03 & 0.00 & 0.05 \\
\hline Change in market HHI & 0.01 & 0.06 & -0.01 & 0.08 \\
\hline Change in store's productivity & 0.14 & 0.81 & 0.91 & 2.44 \\
\hline Change in store's labor demand & 4.30 & 4.11 & 3.94 & 3.39 \\
\hline Change in store's inventory demand & -1.94 & 2.75 & -2.19 & 2.75 \\
\hline NOTE: All numbers are in percenta & . & 9, th & al imp & \\
\hline
\end{tabular}




\title{
Online Appendix: Determinants of Economies of
}

\author{
Scope in Retail
}

Florin Maican ${ }^{1}$ and Matilda Orth $^{2}$

\section{Appendix A: Recovering productivity and demand shocks}

The general labor demand and inventory functions that arise from stores' optimization problem are $1_{j t}=\tilde{l}_{t}\left(\omega_{j t}, \mu_{j t}, k_{j t}, n_{j t}, w_{j t}, \mathbf{x}_{m t}\right)$ and $\mathrm{a}_{j t}=\tilde{a}_{t}\left(\omega_{j t}, \mu_{j t}, k_{j t}, n_{j t}, w_{j t}, \mathbf{x}_{m t}\right)$. To back out $\omega_{j t}$ and $\mu_{j t}$, functions $\tilde{l}_{t}(\cdot)$ and $\tilde{a}_{t}(\cdot)$ must be strictly monotonic in $\omega_{j t}$ and $\mu_{j t}$, which holds under mild regularity conditions of the dynamic programming problem (Pakes, 1994). Maican and Orth (2019) discuss in detail all these conditions required for invertibility. By inverting these policy functions to solve for $\omega$ and $\mu$, we obtain $\omega_{j t}=f_{t}^{1}\left(l_{j t}, k_{j t}, n_{j t}, w_{j t}, a_{j t}, \mathbf{x}_{m t}\right)$ and $\mu_{j t}=f_{t}^{2}\left(l_{j t}, k_{j t}, n_{j t}, w_{j t}, a_{j t}, \mathbf{x}_{m t}\right)$, i.e., the productivity and exogenous shocks are nonparametric functions of the observed variables in the state space and the controls.

In our setting, the estimation of the service-generating function (3) is in two-steps. In the first step, we isolate stores' received demand shocks $\mu_{j t}$ using information about stores' market shares $m s_{j t}$, i.e., $\ln \left(m s_{j t}\right)-\ln \left(m s_{o t}\right)=\rho_{n p} n p_{j t}+\rho_{i n c, 1} i n c_{m t}+\rho_{i n c, 2} i n c_{m t}^{2}+\mu_{j t}+\nu_{j t}$, according to equation (7). The use of another output measure apart from sales of product category, and the distinction between stores' market shares and sales of a category, are important for identification. Our model contains two unobserved shocks and two Markov processes. We show how this additional output equation helps to recover demand shocks separate from productivity and ensures the identification of the model.

\footnotetext{
${ }^{1}$ University of Gothenburg, CEPR, and Research Institute of Industrial Economics (IFN), E-mail: maicanfg@gmail.com

${ }^{2}$ Research Institute of Industrial Economics (IFN), Box 55665, SE-102 15, Stockholm, Sweden, Phone +468-665 4531, E-mail: matilda.orth@ifn.se
} 
By substituting the non-parametric inversion $f_{t}^{2}\left(l_{j t}, k_{j t}, n_{j t}, w_{j t}, a_{j t}, \mathbf{x}_{m t}\right)$ for $\mu_{j t}$ in (7), we obtain an estimate of $b_{t}(\cdot)$ (i.e., predicted market shares, $\hat{b}_{t}$, where $b_{t}(\cdot)=f_{t}^{2}(\cdot)$ ). This allows us to write the shocks $\mu_{j t}$ as a parametric function, i.e., $\mu_{j t}=\hat{b}_{j t}-\rho_{n p} n p_{j t}-\rho_{i n c, 1} i n c_{j t}-\rho_{i n c, 2} i n c_{j t}^{2}$, which will be treated as an input in the multi-output service-generating function.

Inventories can increase from a higher $\mu_{j t}$ and more products in the store, i.e., a higher love-for-variety. New technologies such as bar codes, scanners and business systems affect inventory levels, and positive adjustments avoid stock-outs and increase quality. Technological advances can benefit the existing number of products that the store has in its assortment, e.g., through faster product lines and a higher frequency of turnover. Importantly, however, higher store productivity creates incentives for stores to increase their product variety and increase their size. ${ }^{3}$

By substituting $\mu_{j t}$ (predicted) and $\omega_{j t}$ into (2), the service generating function becomes

$$
y_{i j t}=-\alpha_{y} y_{-i j t}+\phi_{t}\left(l_{j t}, k_{j t}, n_{j t}, w_{j t}, a_{j t}, \mathbf{x}_{m t}\right)+u_{i j t},
$$

where $\phi_{t}(\cdot)=\beta_{l} l_{j t}+\beta_{k} k_{j t}+\beta_{a} a_{j t}+\beta_{x} \mathbf{x}_{m t}+\omega_{j t}+\mu_{j t}$. The estimation of (9) using OLS and the polynomial expansion of order 2 yields an estimate of service output without service output shocks $u_{i j t}$, which gives us $\hat{\phi}_{t}$, which is used to obtain store productivity $\omega_{j t}$ as a function of the parameters, $\omega_{j t}=\hat{\phi}_{j t}-\beta_{l} l_{j t}-\beta_{k} k_{j t}-\beta_{a} a_{j t}-\beta_{q} y_{0 t}-\beta_{x} \mathbf{x}_{m t}-\left(\hat{b}_{j t}-\rho_{n p} n p_{j t}-\rho_{i n c, 1} i n c_{j t}-\right.$ $\left.\rho_{i n c, 2} i n c_{j t}^{2}\right)$. Then, we use the information from the Markov processes to obtain the shocks $\left(\xi_{j t}+u_{i j t}\right)$ and $\left(\eta_{j t}+\nu_{j t}\right)$ as functions of parameters, which are used to form the moment conditions as described in the main text.

\section{Appendix B: Economies of scope: Simulation of the model}

In this section, we discuss how to use the estimated model to compute sales per product. We highlight the channels that drive the increase in sales and the role of economies of scope. For simplicity of exposition, we consider a store $j$ that offers three product categories. We can

\footnotetext{
${ }^{3}$ Viewing the number of products as a measure of store size is in line with Holmes (2001) and is unarguably reasonable when using yearly data such that stores have time to adjust storage places, shelf space, etc., to an increasing number of products. Note that we consider the intensive margin in terms of increasing store size.
} 
rewrite the multi-product sales of store $j$ for each product category as a system of equations

$$
\begin{aligned}
& \ln Y_{1 j t}=-\alpha_{y} \ln \left(Y_{2 j t}+Y_{3 j t}\right)+T_{j t}+u_{1 j t}^{p} \\
& \ln Y_{2 j t}=-\alpha_{y} \ln \left(Y_{1 j t}+Y_{3 j t}\right)+T_{j t}+u_{2 j t}^{p} \\
& \ln Y_{3 j t}=-\alpha_{y} \ln \left(Y_{1 j t}+Y_{2 j t}\right)+T_{j t}+u_{3 j t}^{p}
\end{aligned}
$$

where the term is defined as $T_{j t}=\left(\beta_{l} l_{j t}+\beta_{k} k_{j t}+\beta_{a} a_{j t}\right)+\beta_{q} y_{m t}+\mathbf{x}_{m t}^{\prime} \boldsymbol{\beta}_{x}+\omega_{j t}+\mu_{j t}$, i.e., it includes all store- and market-specific terms. ${ }^{4}$ The system of equations (10) is nonlinear and satisfies the contraction mapping properties, i.e., it has a unique solution, which can be found by using the fixed-point iteration algorithm. The total sales of store $j$ are $Y_{j t}=Y_{1 j t}+Y_{2 j t}+Y_{3 j t}$.

The estimation of the multi-product sales gives $\alpha_{y}$ and $T_{j t}$. A change in the store characteristics (i.e., in $T_{j t}$ ) affects sales of all products in a store with the same magnitude that depends on size of scope parameter $\alpha_{y}$. A change in the market characteristics (part of $T_{j t}$ ) affects sales of a product in two stores different depending on stores' characteristics and size of scope parameter. The system of equations (10) is used to compute product sales after the introduction of a new product. It is important to note that in this example, the number of products is not endogenous, i.e., we do not model the cost with variety. Endogenizing the number of products by modeling the cost with variety has the advantage that a change in scope parameter $\alpha_{y}$ affects stores' optimal variety (first-order condition of store's dynamic optimization changes).

Table B.1 shows the changes in product sales after the introduction of a new product, a decrease in scope parameter (i.e., $\alpha_{y}$ ), and a change in store/market characteristics using a store with three product categories as an example. Going from three to four products yields a drop in sales per product and an increase in total sales (4.31 vs. 4.44). Thus, this finding shows the importance of economies of scope for a store, that is, total sales increase by selling more products with the same resources. Second, a decrease in the scope parameter $\alpha_{y}$ from 0.85 to 0.80 results in a, increase in total sales by 10 percent. For example, economies of scope are important where there is less competition between the products in the store. Third, an increase in term $T_{j t}$ by 20 percent yields an increase in total sales by approximately 60 percent.

\footnotetext{
${ }^{4}$ Note that a store is unique, i.e., it exists only in one market.
} 
Table B.1: Economies of scope: Model simulation example

\begin{tabular}{|c|c|c|c|c|c|c|c|c|}
\hline & \multirow{2}{*}{$\begin{array}{l}\text { Product } \\
\text { shocks }\end{array}$} & \multicolumn{2}{|c|}{ Model parameters } & \multicolumn{5}{|c|}{ Log of sales } \\
\hline & & Scope param. & Store/market term & Prod. 1 & Prod. 2 & Prod. 3 & & Total \\
\hline & & $\alpha_{y}$ & $T_{j t}$ & $y_{1 j t}$ & $y_{2 j t}$ & $y_{3 j t}$ & $y_{4 j t}$ & $y_{j t}$ \\
\hline Main specification & Yes & 0.85 & 6.32 & 3.03 & 3.19 & 3.38 & & 4.31 \\
\hline Main specification & No & 0.85 & 6.32 & 3.09 & 3.09 & 3.09 & & 4.19 \\
\hline Add a new product & Yes & 0.85 & 6.32 & 2.83 & 2.96 & 3.10 & 3.25 & 4.44 \\
\hline Add a new product & No & 0.85 & 6.32 & 2.91 & 2.91 & 2.91 & 2.91 & 4.29 \\
\hline Decrease in $\alpha_{y}$ & Yes & 0.80 & 6.32 & 3.14 & 3.30 & 3.48 & & 4.41 \\
\hline Decrease in $\alpha_{y}$ & No & 0.80 & 6.32 & 3.20 & 3.20 & 3.20 & & 4.30 \\
\hline Increase in $T_{j t}$ by $20 \%$ & Yes & 0.85 & 7.58 & 3.71 & 3.87 & 4.06 & & 4.99 \\
\hline Increase in $T_{j t}$ by $20 \%$ & No & 0.85 & 7.58 & 3.78 & 3.78 & 3.78 & & 4.87 \\
\hline
\end{tabular}

NOTE: The product shocks are $u=\{0.1,0.2,0.3\}$ (three products) and $u=\{0.1,0.2,0.3,0.4\}$ (four products). 